\title{
Coastal Evolution in a Wetland Affected by Large Tsunamigenic Earthquakes in South-Central Chile: Criteria for Integrated Coastal Management
}

\author{
Carolina Martínez ${ }^{1,2,3, *} \mathbb{0}$, Einer Sepúlveda-Zúñiga ${ }^{4}$, Mauricio Villagrán ${ }^{5}$, Octavio Rojas ${ }^{6, *}$, Matías Gómez ${ }^{5}$, \\ Pablo López ${ }^{7}$ and Carolina Rojas ${ }^{3,8}$ (D)
}

1 Instituto de Geografía, Facultad de Historia, Geografía y Ciencia Política, Pontificia Universidad Católica de Chile, Santiago 7820436, Chile

2 Centro de Investigación Para la Gestión Integrada de Desastres Naturales (CIGIDEN), ANID/FONDAP/15110017, Santiago 7820436, Chile

3 ANID-Millennium Science Initiative Program-Instituto Milenio en Socio-ecología Costera (SECOS), Santiago 8331150, Chile; carolina.rojas@uc.cl

4 Programa de Doctorado en Geografía, Instituto de Geografía, Facultad de Historia, Geografía y Ciencia Política, Pontificia Universidad Católica de Chile, Santiago 7820436, Chile; exsepulveda@uc.cl

5 Department of Civil Engineering, Universidad Católica de la Santísima Concepción, Alonso de Ribera 2850, San Andrés, Concepción 4090541, Chile; mvillagran@ucsc.cl (M.V.); mgomez@ing.ucsc.cl (M.G.)

6 Facultad de Ciencias Ambientales y Centro EULA-Chile, Departamento de Planificación Territorial y Sistemas Urbanos, Universidad de Concepción, Concepción 4089100, Chile

7 School of Civil Engineering, Faculty of Engineering, University of Bristol, 93-95, Woodland Road, Office 5.4, Bristol BS8 1US, UK; pablo.lopezfilun@bristol.ac.uk

check for

updates

Citation: Martínez, C.;

Sepúlveda-Zúñiga, E.; Villagrán, M.;

Rojas, O.; Gómez, M.; López, P.; Rojas,

C. Coastal Evolution in a Wetland

Affected by Large Tsunamigenic

Earthquakes in South-Central Chile:

Criteria for Integrated Coastal

Management. Water 2021, 13, 1467.

https://doi.org/10.3390/w13111467

Academic Editor: Federica Rizzetto

Received: 12 April 2021

Accepted: 20 May 2021

Published: 24 May 2021

Publisher's Note: MDPI stays neutral with regard to jurisdictional claims in published maps and institutional affiliations.

Copyright: (C) 2021 by the authors. Licensee MDPI, Basel, Switzerland. This article is an open access article distributed under the terms and conditions of the Creative Commons Attribution (CC BY) license (https:/ / creativecommons.org/licenses/by/ $4.0 /)$.
8 Instituto de Estudios Urbanos y Territorial y Centro de Desarrollo Urbano Sustentable CEDEUS, Pontificia Universidad Católica de Chile, Providencia 7500000, Chile

* Correspondence: camartinezr@uc.cl (C.M.); ocrojas@udec.cl (O.R.)

Abstract: The coastal evolution of the microtidal Tubul-Raqui wetland in south-central Chile ( $\left.36^{\circ} \mathrm{S}\right)$, which historically has been affected by large earthquakes and tsunamis, particularly the 1960 $(\mathrm{Mw}=9.5)$ and $2010(\mathrm{Mw}=8.8)$ subduction earthquakes and their associated tsunamis, is analyzed. Historical aerial photographs and topographic and bathymetric surveys from the 1961-2017 period, as well as salinity, sediment, and flora data obtained following the 2010 earthquake were used for comparison with data from prior to the event. A steady state of the shoreline was established, with an average erosion rate of $-0.016 \mathrm{~m}$ /year in the 1961-2017 period. However, erosion predominated in the period between these two large earthquakes (1961-2009), with an average rate of $-0.386 \mathrm{~m}$ /year. The wetland dried up, partially recovered saline intrusion a year later, and recovered the salinity conditions it had before the earthquake two years later. The postearthquake effects on the floristic composition were not significant, with the species Spartina densiflora, which presented a high tolerance to these types of changes, predominating. Moreover, 75 percent of the taxa in pre- and postearthquake conditions coincided, with the halophyte species Spartina densiflora, Sarcocornia fructicosa, and Cotula coronopifolia predominating, while the best-conserved community was Spartina-Sarcocornia association located in the saltmarsh. Seven years after the earthquake, the shoreline presented an accretion rate of $2.935 \mathrm{~m} /$ year; if the current tectonic conditions prevail, an erosive trend can be expected in the coming decades. The morphological variability and the changes associated with the shoreline in this wetland are strongly controlled by tectonic factors. Criteria aimed at integrated coastal management to promote its occupancy and use in accordance with its evolutionary dynamics are proposed.

Keywords: coastal evolution; geomorphological change; wetland; earthquakes; coastal management 


\section{Introduction}

Coastal wetlands are currently the object of worldwide concern, given the heavy anthropization of the coastal zone and the need for climate change adaptation mechanisms. In addition to being the most biologically productive ecosystems and important sources of biological diversity, water reservoirs are responsible for high primary productivity [1]. Due to their fragility and delicate ecological equilibrium, they are susceptible to anthropogenic and natural disturbances that determine their functioning and variability [2].

In this respect, research on natural disturbances associated with earthquakes and tsunamis that affect coastal wetlands on a geological scale is well represented (e.g., coseismic subsidence rates for large earthquakes, their relationships with paleotsunamis, and ancient sea levels) [3-14]. However, for historical and short-term scales, research has been limited, and there has been little systematization of the function of violent disturbances such as earthquakes and tsunamis in recovery and change adaptation mechanisms in coastal wetlands [15-19]. An understanding of such changes and the ways in which the coast readapts is fundamental for guiding the use and forms of occupancy of the coast, given the increase in extreme events in the last decade (typhoons, hurricanes, meteotsunamis, storm surges) and the increasingly destructive damage caused by earthquakes and tsunamis [20-26]. Moreover, these adaptive characteristics, in addition to maintaining the essential functions of the coast, are an indicator of system resilience $[27,28]$. Studies that integrate the physical, ecological, biogeochemical, and geomorphic responses of estuaries to sea level rise [29] or any other type of change in water level are fundamental to bridging the remaining knowledge gap for better coastal zone management.

In Chile, the study of coastal wetlands has been approached mainly in terms of biological diversity, in keeping with the worldwide trend [29-37], and the effects of urbanization [38-40]. Dura et al. [14] recently studied the frequency of large tsunamigenic earthquakes using records of sediment deposits in ancient wetlands of the coast of central Chile $\left(33^{\circ} \mathrm{S}\right)$. Nonetheless, little is known about the natural change factors in these environments that would allow their integration into coastal management plans such that uses could be planned in accord with the functioning and natural dynamics of the wetlands that are continually exposed to earthquake and tsunami phenomena.

In central Chile $\left(32^{\circ}-37^{\circ} \mathrm{S}\right)$, the $\mathrm{Mw}=8.8$ earthquake of 27 February 2010 and the associated tsunami generated widespread destruction along $600 \mathrm{~km}$ of the coast, causing major morphological, social, and environmental changes [41-43]. Coastal uplift of up to $1.8 \mathrm{~m}$ occurred on the coast of Lebu $\left(37^{\circ} \mathrm{S}\right)$, uncovering shore platforms and resulting in changes in the intertidal zone and drying of wetlands [44-47].

One of the most affected coastal wetlands was Tubul-Raqui $\left(36^{\circ} \mathrm{S}\right)$, the aquatic components of which underwent significant modifications, especially in the intertidal marshes, which partially dried up [48-50]. Here, the magnitude of coastal uplift was $1.4 \mathrm{~m}$, which interrupted the entry of the tide that allowed the saltmarsh to be maintained, causing a significant ecosystem impact, mainly due to the mortality of benthic macroinvertebrates [44-46,51,52]. According to [53,54], coastal uplift produced limitations on the exchange of river flow with the ocean, causing a decrease in the salinity of the water in the wetland, severely affecting the two most important benthic species for artisanal fishing, the alga pelillo (Gracilaria chilensis) and the bivalve razor clam (Ensis macha), with no evidence of any degree of recolonization.

Since the 1960 earthquake, the Chilean coast had not been affected by a large-magnitude earthquake and tsunami with such violent modifications of the coastal geomorphology, which has brought about the need to investigate the change factors of a tectonic coast to generate applications on a land-use planning and coastal management scale since the urbanization processes underway in the country have developed around coastal axes, forming new metropolitan areas and in turn new coastal axes [55,56]. In addition, the need for adaptation mechanisms requires an understanding of how to plan human settlements and urban expansion in safe areas by considering given climate change scenarios [57]. In 
rural communities and especially fishing coves, these mechanisms are urgent due to their dependence on natural resources and the need to conserve coastal marine ecosystems.

Thus, the purpose of this investigation is to analyze historical-scale coastal evolution in the Tubul-Raqui wetland during the period between the two large subduction earthquakes (1960 and 2010) in order to propose criteria for integrated coastal management in coastal areas affected on a recurring basis by these phenomena. The paper also includes the effects of the reconstruction process following the 2010 earthquake, 10 years on from the disaster, to illustrate how an understanding of the changing factors of this type of coast can influence improvements in decision making and contribute to planning for coastal resilience by allowing the reorganization and adaptation of the natural system and its ability to maintain its functions or regain them to be considered [58].

\section{Geographical Context}

On the coast of the Biobío Region $\left(36^{\circ}-38^{\circ}\right.$ S), especially on the coastal plain, there are numerous extensive wetland zones that make up valuable environmental heritage. Among them, the Tubul-Raqui wetland stands out for its high biodiversity [49] and as the foundation for the local economy of a small rural community [59]. This coastal wetland of south-central Chile is characterized by a large saltmarsh with the development of esparto and vegetation adapted to salinity variations [29,60-62]. It is surrounded by shore platforms up to $300 \mathrm{~m}$ and intermittently flooded plains used for livestock activity or subsistence agriculture.

The Tubul-Raqui wetland $\left(37^{\circ} 13^{\prime} \mathrm{S}-73^{\circ} 26^{\prime} \mathrm{W}\right)$ is formed by the confluence of the Tubul and Raqui rivers, which flow through two interconnected coastal basins of about $274 \mathrm{~km}^{2}$ that drain directly into the Gulf of Arauco (Figure 1, $\pm 1.0 \mathrm{~m}$ of tidal range) [63]. The area has a Csb Mediterranean climate (warm summer) with oceanic influence and rainfall concentrated in winter [64]. In geological terms, it is located in the sedimentary basin of the Arauco Peninsula, is from the Cretaceous age, and is composed of Quiriquina, Tubul, Pilpilco, and Ranquil formations [65].

Starting in the 1960s, an organized group of fishermen and alga (Gracilaria chilensis or "pelillo") collectors established itself here, forming a settlement of about 2000 inhabitants. Until the earthquake of 27 February 2010, this town was the center of social and economic organization of Tubul Cove $[59,66]$. 

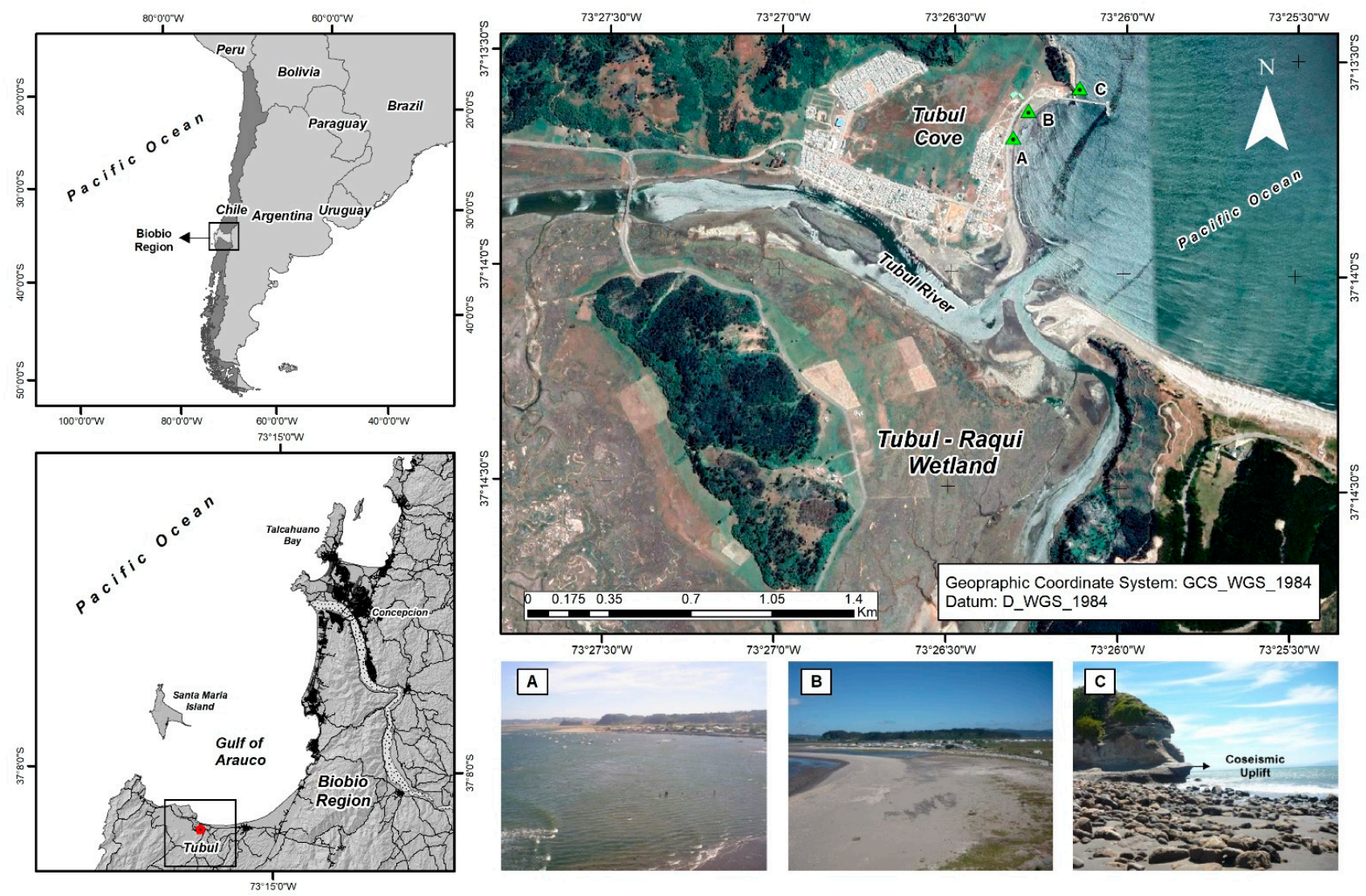

Figure 1. Study area. The figure on the left shows the context of the location of the Tubul-Raqui wetland on the interior of the Gulf of Arauco, on the south-central Chilean coast: (A) (view from point A to E), (B) (view from point B to SE), and (C) (view from river mouth to point $C$ toward $N W$ ) show pre- and postearthquake morphological changes, indicating their location on the coastal area of the wetland; (A) shows the marine zone next off Tubul Cove in pre-earthquake conditions, which is now an intertidal zone of Tubul Beach due to coastal uplift produced by the earthquake. Here, a beach approximately $100 \mathrm{~m}$ wide was formed (B); (C) shows the marine abrasion platform that emerged due to coastal uplift measured at $1.4 \mathrm{~m}$ by Quezada [44] after the 2010 earthquake.

\section{Materials and Methods}

Three groups of data were collected for pre- and post-2010 earthquake conditions: (a) topography and bathymetry to determine morphological changes; (b) a salinity parameter (PSU), used to demonstrate the recovery of saline intrusion; and (c) wetland floristic and vegetation composition.

In addition, through the coupling of the process-based model Delft 3D FLOW [67] for morphological response and the wave propagation model Delft 3D WAVE [68], the changes in the morphological response of the coastline induced by coseismic shifts occurring during the 27 February 2010 earthquake were evaluated for regular and storm wave conditions.

\subsection{Field Data Collection}

\section{(a) Morphological Changes}

The morphological changes in the wetland were determined based on shoreline variations in the 1979-2017 period, that is, before and after the 27 February 2010 earthquake conditions. The methodology proposed by Martinez et al. [69], employing the use of aerial photographs from different years and precise topographic surveys for the generation of a historical database, was used. The aerial photographs were georeferenced and digitized, with mean quadratic errors (RMS) of less than $1 \mathrm{~m}$ obtained (Table 1). The topographical surveys were carried out in winter and summer between 2010 and 2015. For this purpose, 
topographic instruments (GPS, Trimble, model R-4) with submeter precision (mm) were used. The changes in the shoreline were determined by superimposing maps in the GIS platform (ArcGis 9.3), using three equidistant segments every $100 \mathrm{~m}$. Three beach profiles (P1, P2, P3) were also located, in which sediment was collected from the surf, beach-face, and backshore zones (Figure 2). For each zone, a surface sediment sample (120 gr) was collected manually and stored in a plastic bag labeled with an alphanumeric code. The sediment was analyzed by sieving in the Physical Geography Laboratory of the Universidad de Concepción. The sediments were sieved using a Ro-Tap mechanical stirrer (RETSCH Mod. AS 200 brand) and dried at a constant temperature of $100{ }^{\circ} \mathrm{C}$ in a universal forced convection oven (MEMMERT Mod. ULM 700 brand) [70]. For the textural size classification, the Wentworth [71] classification was used. The mean diameter (mean size) and the dispersion parameters (asymmetry) were obtained by statistical analysis using the criteria of Folk and Ward [72]. The Trask (So) selection or classification coefficient (sorting index, therefore, $\left.=\mathrm{D}_{75} / \mathrm{D}_{25}\right)$ was also included [73].

Table 1. Aerial photographs used in the determination of the planform changes of the shoreline and the mean squared error. In general, all of the errors were less than $1 \mathrm{~m}$.

\begin{tabular}{ccccc}
\hline Name & Year & Scale & CDP & RMS/ \\
\hline SAF CH-30 & 1979 & $1: 30,000$ & 0.38 & 0.46 \\
SAF CH-60 & 1983 & $1: 60,000$ & 0.64 & 0.47 \\
FONDEF & nov 1992 & $1: 20,000$ & 0.32 & 0.20 \\
MINVU & oct 1999 & $1: 10,000$ & 0.53 & 0.39 \\
SAF & mar 2010 & $1: 20,000$ & 0.21 & 0.28 \\
\hline CDP*: representativeness of the pixel. RMS: root mean square & &
\end{tabular}

$\mathrm{CDP}^{*}$ : representativeness of the pixel. RMS: root mean square.

For the determination of vertical changes at the bottom of the Tubul River and Bay, detailed bathymetries were carried out using an echosounder in the summers of 2011, 2012, and 2013. A portable echosounder with built-in GPS (GARMIN brand, model FF 400C GPsMap 420s) and a maximum depth of $400 \mathrm{~m}$ was used, which was installed aboard a boat. The depth data were referenced to a Chart Datum (CD), estimated by applying the approach suggested by Pawlowicz et al. [74] using two HOBO pressure sensors installed in the Tubul River and the marine zone off Tubul Cove (denoted by a star in Figure 2A). These sensors recorded tidal variations for at least 15 days, with a recording interval of $5 \mathrm{~min}$, recording the spring tides of the month. For pre-earthquake conditions, a precise bathymetric survey carried out in summer 2008 by the Hydraulic Works Department of the Ministry of Public Works (DOH-MOP) [75] was available. Using both surveys, vertical changes were compared through two topo-bathymetric beach profiles, denoted by PB-1 and PB-2 (see Figure 2A).

\section{(b) Salinity and Recovery of Marine Intrusion}

Salinity (practical salinity units (PSU)) measurements were taken using a multiparameter probe (Horiba U-10) at six stations in the Tubul River and seven stations in the Raqui River (Figure 2B). These data were collected in spring tide conditions for a tidal cycle according to the methodology of Perillo and Piccolo [76]. To determine the presence of a saline wedge in the estuary, salinity was measured in both the deep and surface layers of the water. The stations that presented a depth of less than $0.5 \mathrm{~m}$ were considered the surface layer [76]. To classify the data, the criteria of Madden et al. [77] were used. To analyze possible changes in the shape of tidal waves inside the wetland, two HOBO pressure sensors were installed in the Tubul River and the adjacent marine zone during the periods from 18 March to 19 April 2011, and 16 December 2011 to 16 January 2012. These data were compared with tide data from the Tubul River from before the earthquake (17-31 January 2008), available from the Ministry of Public Works (MOP) [75]. 


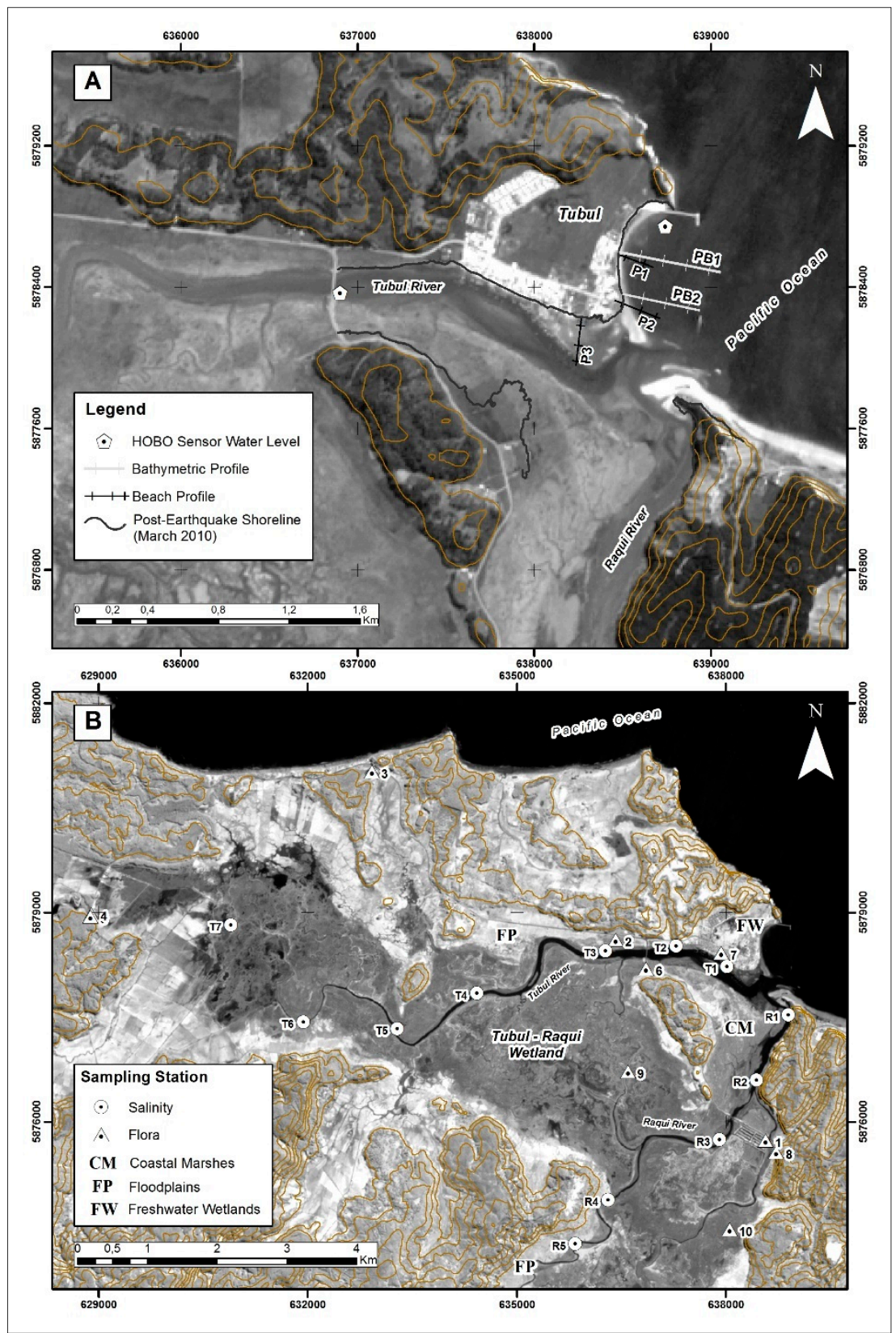

Figure 2. Study area and sampling design: (A) indicates the location of the beach and topobathymetric profiles, principally within the intertidal zone, an area substantially affected by the coastal uplift from the earthquake of 27 February 2010. The locations of the pressure sensors in the Tubul River and the adjacent marine zone, which were used to obtain tidal records, are also indicated with stars. The changes in the relative shoreline position in two segments of the coastal zone of the wetland are indicated as separate $100 \mathrm{~m}$ sections; (B) indicates the locations of the salinity and flora sampling stations in the interior of the Tubul (T) and Raqui (R) rivers and the saltmarsh, respectively. Salinity (PSU) measurements were carried out using a multiparameter probe at six stations in the Tubul River and seven stations in the Raqui River.

For the tide analysis, the methodology proposed by [74] was used, which employs routines in MATLAB that are a translation of the original routines of Foreman 1977 in [74] FORTRAN program. Harmonic and nonharmonic analyses were carried out to determine their regime [78]. With the harmonic constituents obtained, a forecast for the same period was made to compare these values with the observed values. To this end, a residual and 
correlation analysis of both series was carried out. The correlation between the observed and forecast data was $\mathrm{R}^{2}=0.96$.

\section{(c) Floristic Studies}

In order to compare the floristic composition and vegetation structure in pre- and postearthquake conditions, four sampling stations for 2009 and 10 sampling stations for 2012, 2014, and 2016 were established (Figure 2B). The samplings were carried out at exactly the same geographical coordinates, randomly distributed throughout the wetland area.

The vegetation sampling was carried out according to the Braun-Blanquet [79] approximation, categorizing each taxon according to a total coverage scale in quadrants, with 10 one-square-meter quadrants. For measuring abundance, the coverage percentage of the emergent marsh species, which was obtained by observing the area of the quadrant occupied by each plant species, was used. To identify the species, material samples were collected for subsequent identification, using reference information [60,80-84], and direct comparison with specimens deposited in the CONC herbarium of the Universidad de Concepción. For each sampling station, the community parameters of richness (S), abundance (N), Simpson diversity index (1-D) [85], Shannon diversity index $\left(\mathrm{H}^{\prime}\right)$ [86] Pielou evenness $\left(\mathrm{J}^{\prime}\right)$ [87], and dominance (D) were estimated. To this end, the Diversity module of PAST [88] was used.

\subsection{Numerical Modeling}

The numerical model used in this investigation was the Delft 3D model developed by Deltares, which allows 1D, 2DV, 2DH, and 3D modeling of both hydrodynamics and the morphological evolution of the beach zone. The model uses nested grids to increase the resolution in the zones of greatest interest and couples two calculation modulesSWAN [89] and FLOW [67] - to incorporate wave propagation and then morphological and hydrodynamic effects.

To quantify the hydrodynamic effects, the model solved the unsteady shallow water equations. Sediment transport was calculated using the Van Rijn [90] equation for total transport based on the integrated vertical advection-diffusion equation. Morphological changes occur on time scales between 1 and 2 orders of magnitude greater than those of hydrodynamic changes [91]. Therefore, sea bottom changes were calculated by amplifying the sediment transport effects, estimated at each hydrodynamic time step. This amplifying factor, called MORFAC [92], varied by analysis type, that is, different MORFACs were applied for regular and storm waves. This approximation allowed us to accelerate morphological changes to hydrodynamic times and thereby immediately update the bathymetry after each iteration. The numerical model used considered the entire Gulf of Arauco area, with seven sectors modeled in detail. The model details and calibration were described by Gomez et al. [93], and in this investigation, only the results associated with the Tubul-Raqui wetland mouth were used.

In Figure 3, the dimensions of the nested grids used to model wave propagation and the smaller grids associated with each beach for studying morphological effects are shown. The detail grid for the Tubul sector has a resolution of $15 \mathrm{~m} \times 20 \mathrm{~m}$, ensuring a resolution sufficient for detecting local morphological changes. The tide was modeled based on 15 main tide components. In addition, the different wave conditions were determined from a statistical analysis of deep-water waves extracted from the Wave Watch III $[93,94]$ data series for node $37^{\circ} 0^{\prime} \mathrm{S} 74^{\circ} 0^{\prime} \mathrm{O}$, located off the coast of the Gulf of Arauco. Wave climate details can be found in Gomez et al. [93]. The summary parameters used for the modeling, their corresponding MORFAC, and modeling times can be seen in Table 2. 


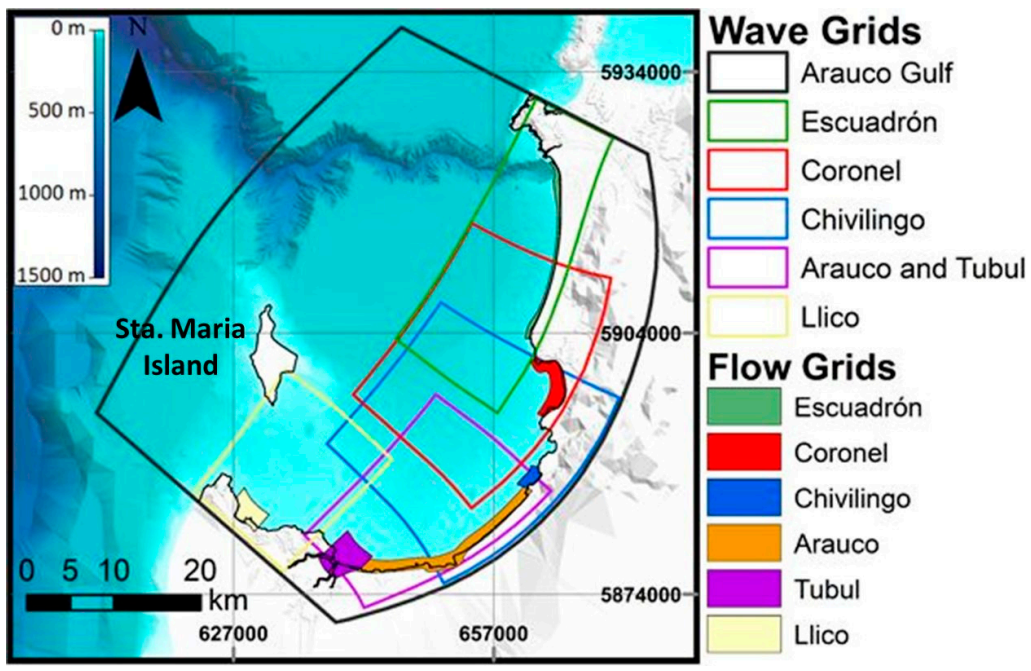

Figure 3. Nested and detailed grids used in the numerical model with Delft 3D. Vertical scale shows depth in $\mathrm{m}$; horizontal scale shows length in $\mathrm{km}$.

Table 2. Wave parameters (deep water), MORFAC, and modeling times used for the numerical simulations.

\begin{tabular}{ccccccc}
\hline \multirow{2}{*}{ Wave Condition } & \multicolumn{3}{c}{ Spectral Parameters } & MORFAC & $\begin{array}{c}\text { Modeling Time } \\
\text { (Tidal Cycles) }\end{array}$ \\
\cline { 2 - 4 } & Hs & Tp & Dp & & 2 \\
\hline Regular-winter & $3.03 \mathrm{~m}$ & $12.6 \mathrm{~s}$ & $233.1^{\circ}$ & 30 & 2 \\
Regular-summer & $2.66 \mathrm{~m}$ & $12.3 \mathrm{~s}$ & $231.7^{\circ}$ & 30 & 4 \\
Storm & $5.51 \mathrm{~m}$ & $10.9 \mathrm{~s}$ & $341.4^{\circ}$ & 6 & 4 \\
\hline
\end{tabular}

Note: HS: significant wave height, Tp: Spectral peak period, Dp: average wave direction.

To consider the effect of coseismic shifts, a seafloor uplift of $1.4 \mathrm{~m}$ was generated, in accordance with the observations of Martinez et al. [19] for this area. The simulations considered the same spectral wave parameters and tidal forcings but with different depths in order to determine morphological behavior changes in the area before and after the earthquake.

\section{Results}

\subsection{Pre- and Postearthquake Geomorphological Changes}

The shoreline of the Tubul-Raqui wetland (segment 1, or marine segment, extends from point $B$ to point $A^{\prime}$ in Figure 4) presented an average variability of $-28.27 \mathrm{~m}$ in the last 36 years and a mean retreat rate of $-1.32 \mathrm{~m} /$ year. On the banks of the Tubul River (segment 2, or estuarine segment, extends from point A to point B in Figure 4), the mean advance rate was $0.57 \mathrm{~m} /$ year (Figure 4). The changes in the shoreline indicate major morphological variability, especially in low-tide conditions (Figure 5). 

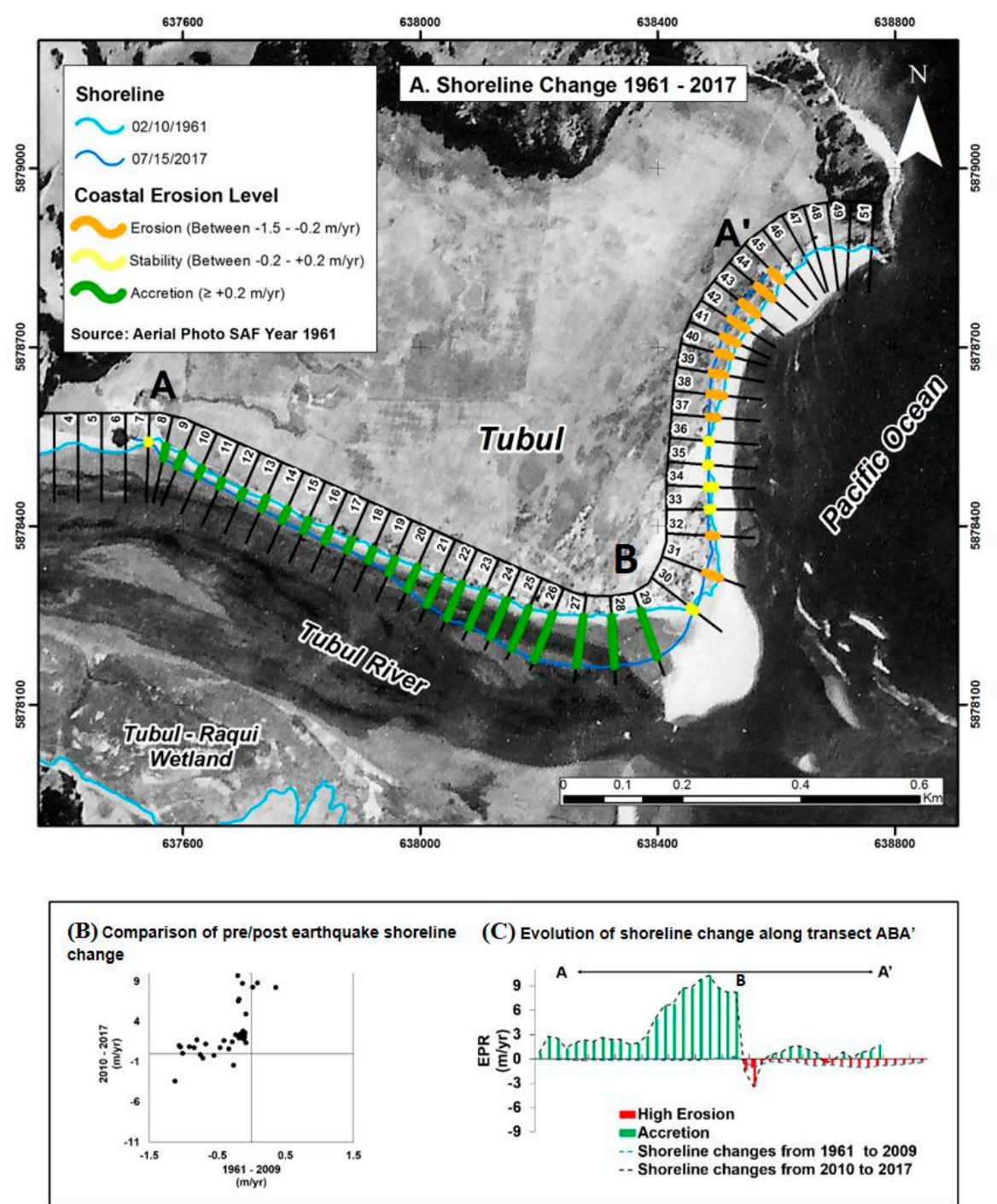

Figure 4. (A) Average change rate (m/year) of the shoreline in two segments of the estuarine zone of the Tubul River, considering a period of 36 years (1961-2017). Green lines indicate accretion, yellow lines indicate stability, orange lines indicate moderate erosion, and red lines indicate strong erosion. In segment 1 (BA'), or marine zone, an erosive process was observed, with erosion values between -1.5 and $-0.2 \mathrm{~m} /$ year recorded. Meanwhile, in segment 2 (AB), or estuarine zone, an initial accumulation of sediment was measured, with an average accretion rate of $\geq 0.2 \mathrm{~m}$ /year. (B) This erosive trend in the marine zone constitutes a continual process in the analyzed time period, which, although decreased in magnitude as a result of the coastal uplift induced by the 27 February earthquake, was not reversed. (C) Along the $\mathrm{ABA}^{\prime}$ transect the differentiated behavior of the coastline is observed, exposed to the dominance of the waves ( $\left.\mathrm{A}^{\prime}-\mathrm{B}\right)$ and to the tides (river-sea) (B-A).

In Figure 5A, the period between two large earthquakes (post-1960 event) was analyzed; a strong erosive trend was observed, with shoreline retreat values between -1.5 and $-0.2 \mathrm{~m}$ /year, consistent with the interseismic period. In Figure $5 \mathrm{~B}$, the postearthquake period (2010-2017) was analyzed, in which the coastal uplift caused a widening of the intertidal zone and accretion processes, explaining the accretion trend in most of the estuarine zone. Even so, some parts of the exposed beach present values corresponding to stability and erosion. 


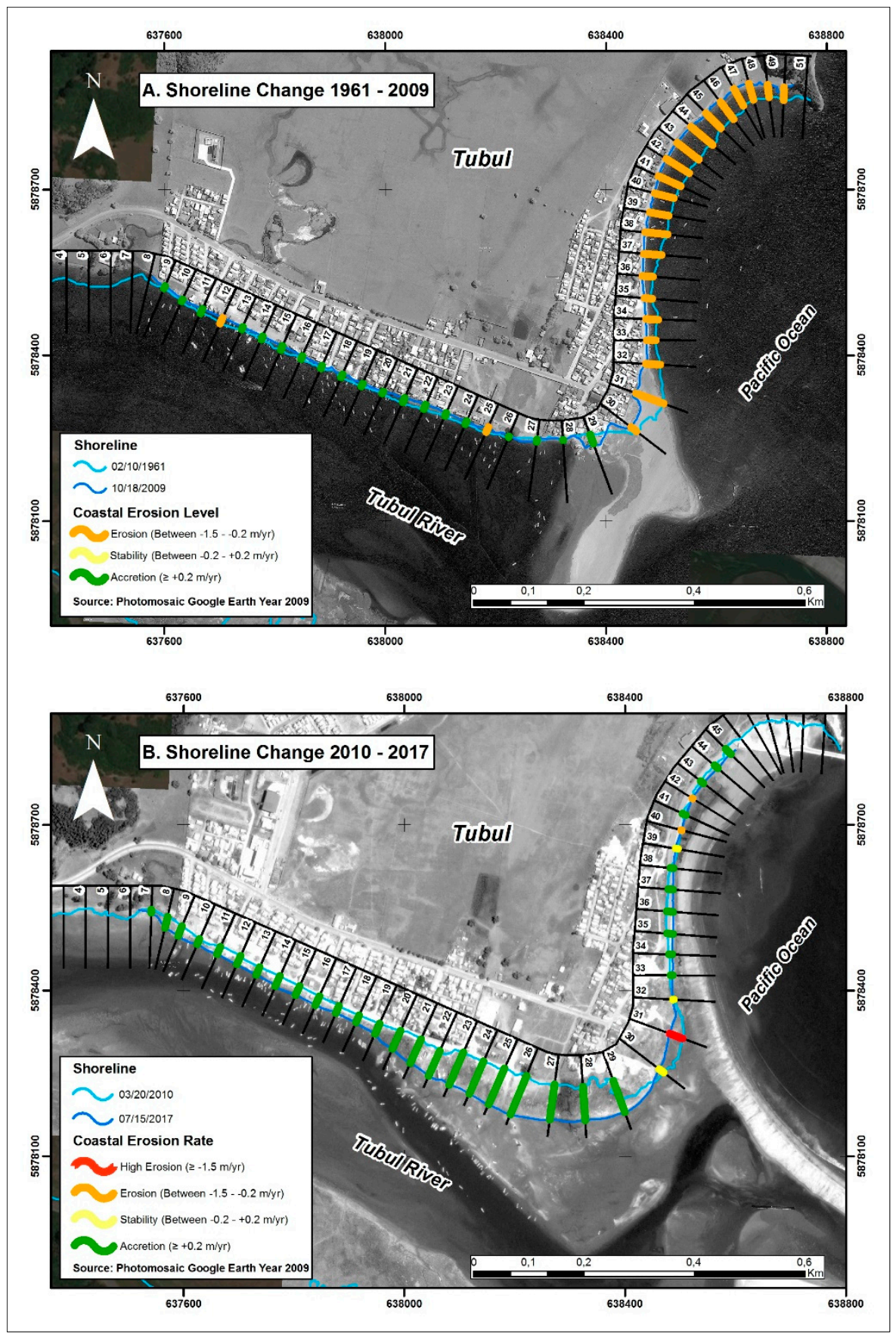

Figure 5. The shoreline changes in two time periods are presented: (A) shows shoreline evolution between 1961-2009; (B) shows shoreline evolution between 2010-2017. Green lines indicate accretion, yellow lines indicate stability, orange lines indicate moderate erosion, and red lines indicate strong erosion. 
The bathymetric changes in Tubul Bay established an average variability of $-0.45 \mathrm{~m}$ in the PB-1 profile in the 2008-2013 period (Table 3 and Figure 6). In general, the topobathymetric profiles presented wide variability in postearthquake conditions (Figures 7 and 8), which was in turn reflected in beach profiles P1 and P2. Profile P3, because it is located in an area that is more protected from wave action, did not present major geomorphological changes during the year.

Table 3. Bathymetric changes in Tubul Bay, pre- and postearthquake in the 2008-2013 period. The main values are on the order of $0.40 \mathrm{~m}$, indicating a decrease in depth.

\begin{tabular}{|c|c|c|c|c|}
\hline Profile 1 & Year 2008 & Year 2011 & Year 2012 & Year 2013 \\
\hline Average (m) & -3.512 & -3.085 & -3.368 & -3.062 \\
\hline Difference $(\mathrm{m}) *$ & & -0.426 & -0.144 & -0.45 \\
\hline Profile 2 & Year 2008 & Year 2011 & Year 2012 & Year 2013 \\
\hline Average (m) & -2.586 & -2.532 & -3.023 & -2.601 \\
\hline Difference $(\mathrm{m})$ * & & -0.054 & 0.436 & 0.014 \\
\hline
\end{tabular}

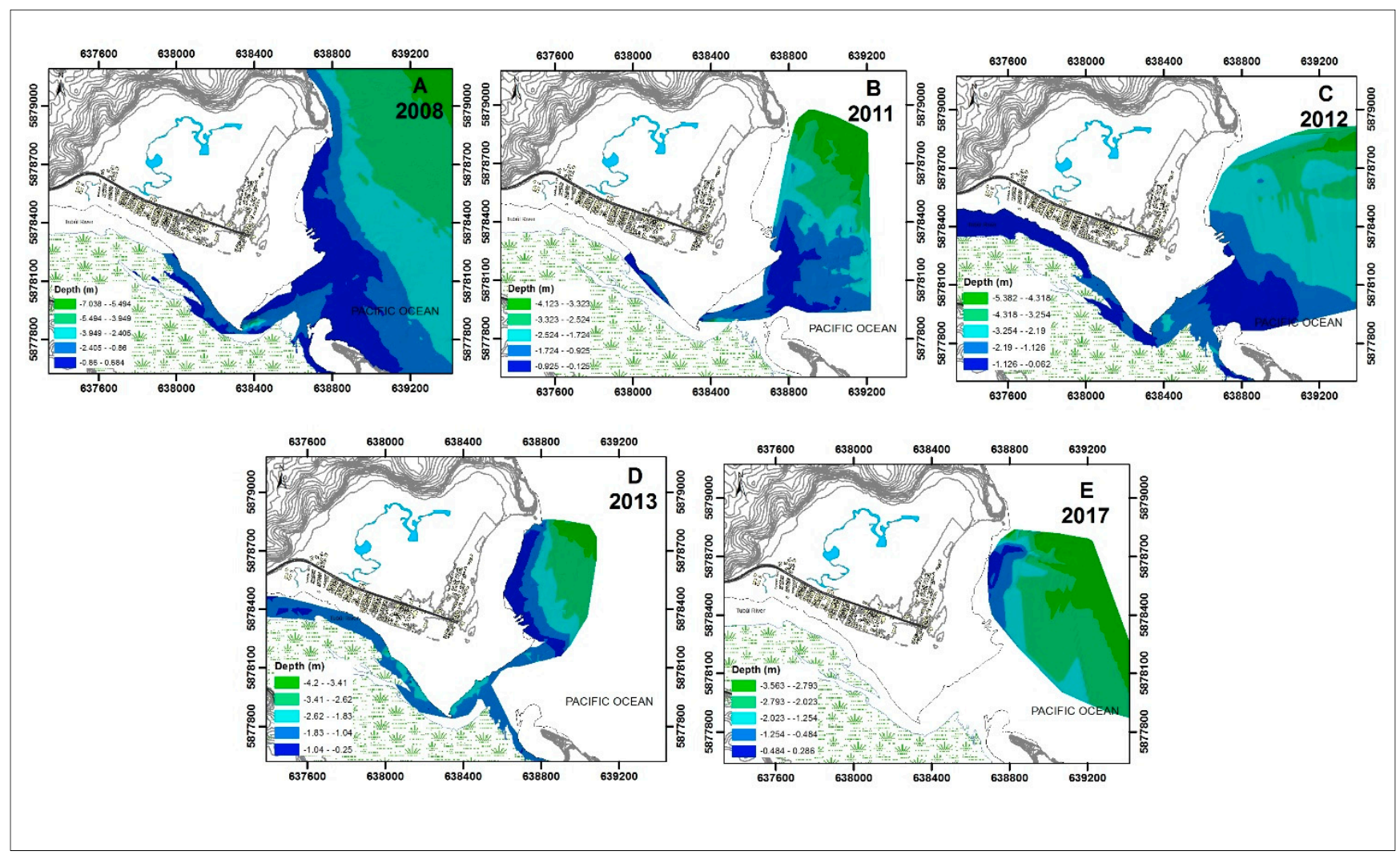

Figure 6. Bathymetry of Tubul Bay, in pre- and postearthquake conditions. The figure presents four bathymetric surveys carried out between 2008 and 2017 (A-E). In the last three (C-E), the effect of the earthquake is registered as generating shallower depths in the adjacent oceanic zone. 


\section{A) Bathymetric Profile of PB-1}

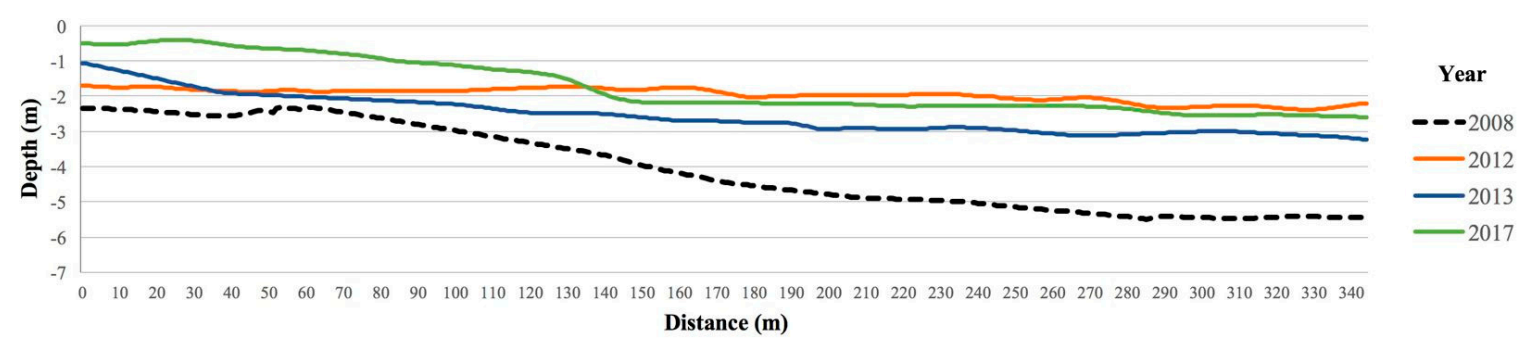

B) Bathymetric Profile of PB-2

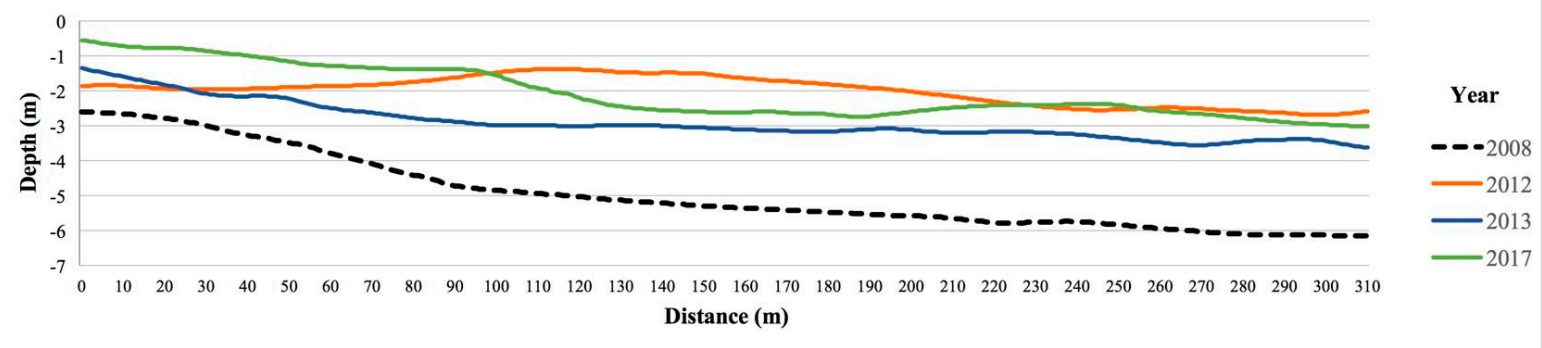

Figure 7. Bathymetric profiles pre- and postearthquake, Tubul Bay. The bathymetric profiles surveyed in the period of 2008-2013 were compared. In both profiles (A,B), a decrease can be observed in the depths with an average of -0.45 in profile PB-1. See Figure 2A for the location of each profile.

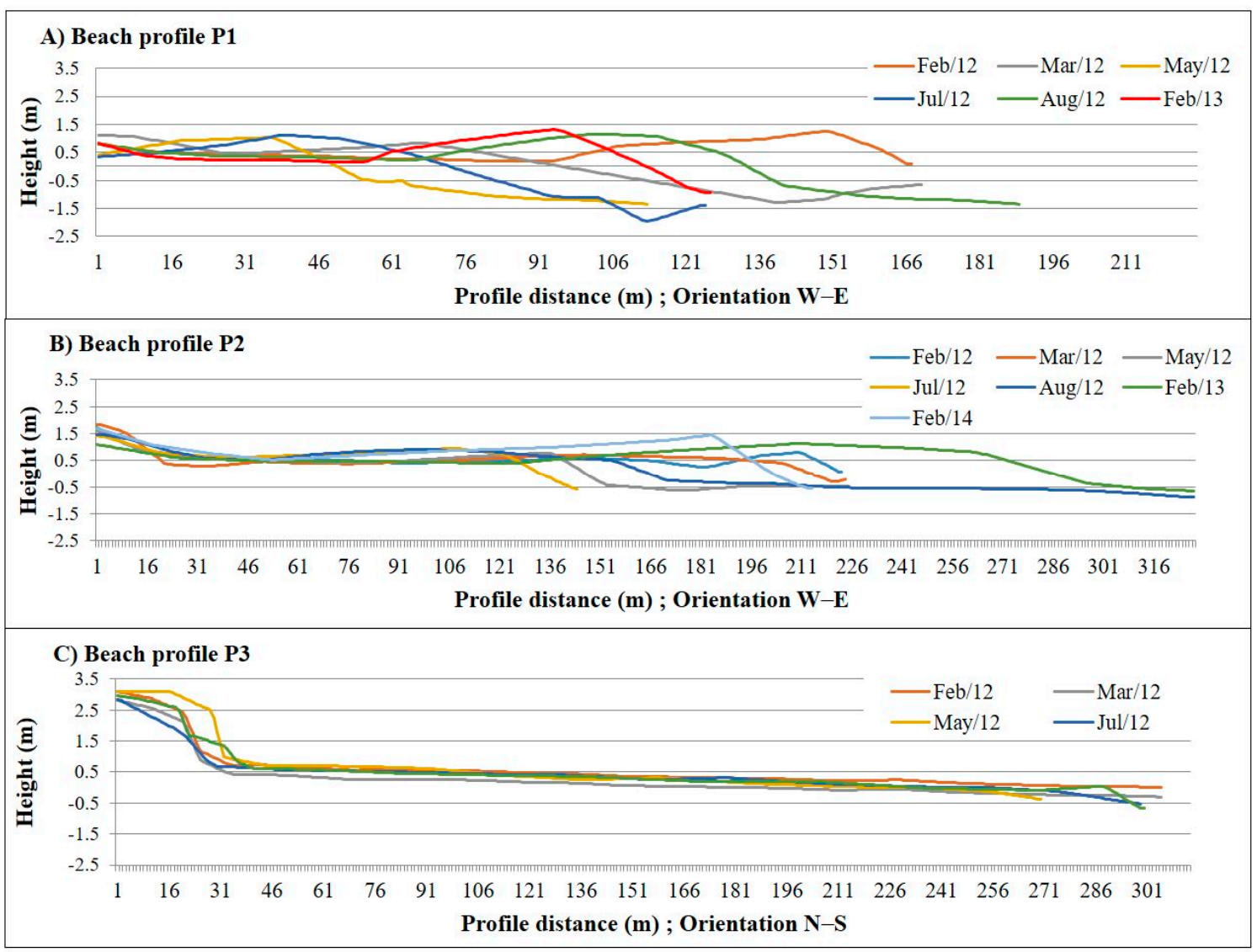

Figure 8. Beach profiles, Tubul Bay. The beach profiles were surveyed in postearthquake conditions on a seasonal basis (winter-summer). They present wide variability $(\mathbf{A}, \mathbf{B})$, with the exception of profile $3(\mathbf{C})$, which is located in a more protected area of the bay. See Figure 2A for the location of each profile. 
In the three analyzed profiles, the mean beach particle size fluctuates between medium and fine sand for the surf and beach-face zones, with fine sand predominating in profile P3. The surf zone sediment was leptokurtic and with moderate sorting, while that of the beach face was mesokurtic and moderately well sorted (Figure 9 and Table 4).

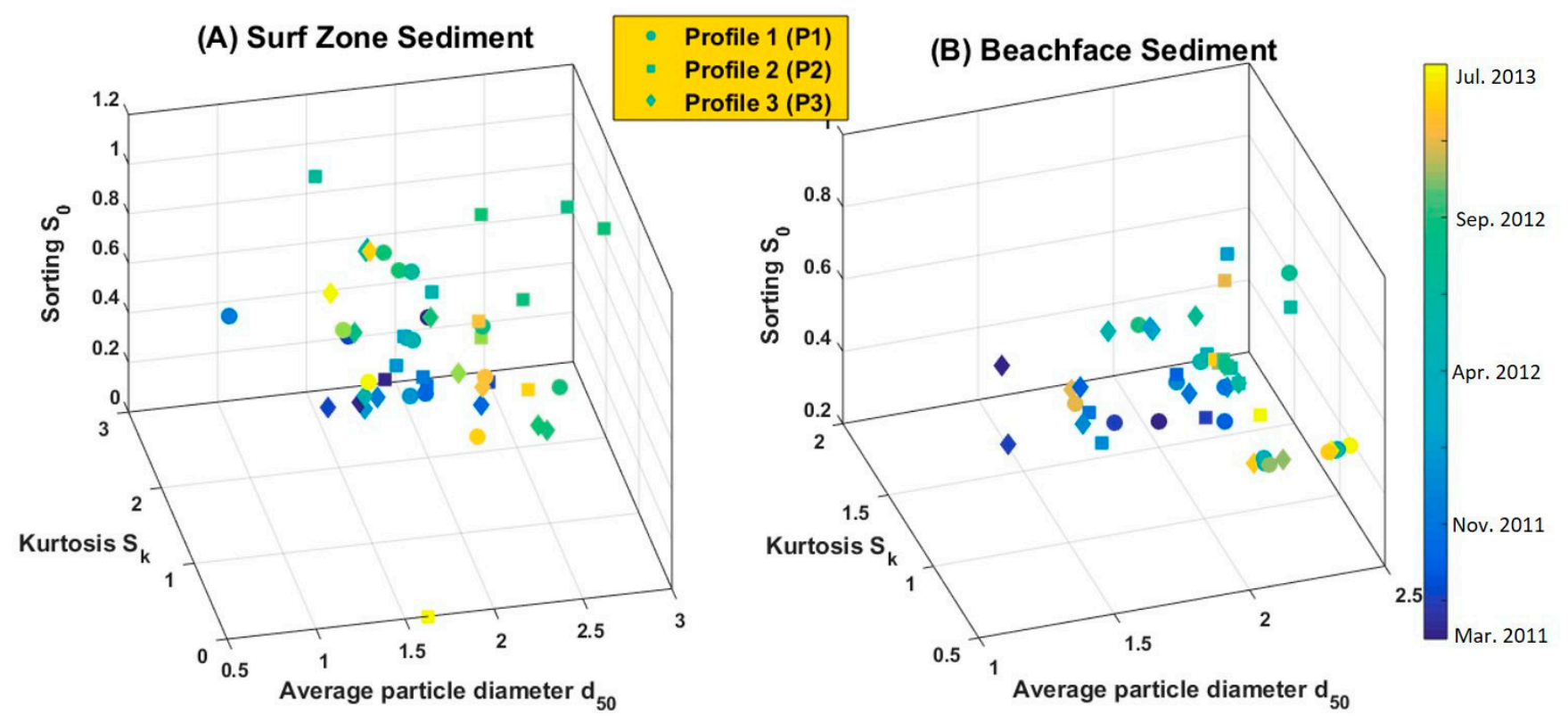

Figure 9. Four-dimensional plotting of statistical parameters of sediments at the surf zone (A) (left) and at the beach-face zone (B) (right). Main parameters plotted are average particle diameter $\left(\mathrm{d}_{50}\right)$, kurtosis $\left(\mathrm{S}_{\mathrm{k}}\right)$, and sorting $\left(\mathrm{S}_{0}\right)$. Color bar indicates the evolution in time, from March 2011 (dark blue) until July 2013 (yellow).

Table 4. Statistical parameters of the beach-face and surf zone sediment. Mean values, kurtosis, and sorting (values lower than 1.6 indicate a good classification, values between 1.6 and 1.9 indicate a moderate or medium rating, and values above 1.9 indicate a poor rating) for the three beach profiles are presented in the table. In general, the surf zone sediment presented leptokurtosis and moderate sorting, while the beach-face sediment was mesokurtic and moderately well sorted. The average size in all profiles corresponded to medium or find sand.

\begin{tabular}{|c|c|c|c|c|c|c|c|c|c|c|c|c|}
\hline Date & $\begin{array}{l}\text { Average } \\
\text { Size } \varphi\end{array}$ & Type & $\begin{array}{c}\text { Kurtosis } \\
\mathrm{S}_{\mathrm{k}}\end{array}$ & $\begin{array}{c}\text { Sorting } \\
\mathrm{S}_{\mathrm{o}}\end{array}$ & $\begin{array}{l}\text { Average } \\
\text { Size } \varphi\end{array}$ & Type & $\begin{array}{c}\text { Kurtosis } \\
\mathrm{S}_{\mathrm{k}}\end{array}$ & $\begin{array}{c}\text { Sorting } \\
\mathrm{S}_{\mathrm{o}}\end{array}$ & $\begin{array}{l}\text { Average } \\
\text { Size } \varphi\end{array}$ & Type & $\begin{array}{c}\text { Kurtosis } \\
\mathrm{S}_{\mathrm{k}}\end{array}$ & $\begin{array}{c}\text { Sorting } \\
\mathrm{S}_{\mathrm{o}}\end{array}$ \\
\hline & \multicolumn{4}{|c|}{ Profile N1 (P1) } & \multicolumn{4}{|c|}{ Profile N2 (P2) } & \multicolumn{4}{|c|}{ Profile N3 (P3) } \\
\hline Surfzone & 1.75 & $\begin{array}{l}\text { Medium } \\
\text { sand }\end{array}$ & 1.21 & 0.72 & 1.75 & $\begin{array}{l}\text { Meddium } \\
\text { sand }\end{array}$ & 1.28 & 0.64 & 2.03 & $\begin{array}{l}\text { Fine } \\
\text { sand }\end{array}$ & 1.31 & 0.78 \\
\hline Beachface & 2.07 & $\begin{array}{l}\text { Fine } \\
\text { sand }\end{array}$ & 0.89 & 0.52 & 1.85 & $\begin{array}{l}\text { Mediun } \\
\text { sand }\end{array}$ & 1.02 & 0.57 & 2.01 & $\begin{array}{l}\text { Fine } \\
\text { sand }\end{array}$ & 0.95 & 0.63 \\
\hline
\end{tabular}

\subsection{Salinity and Recovery of Marine Intrusion}

The effect of coastal uplift caused by the 27 February 2010 earthquake on the wetland was observed until 2011, the time when the salinity values were minimal at all stations. The Tubul River was only accessible up to station 2, while the low depth of the Raqui River made it impossible to reach any station by boat (Figure 10). In postearthquake conditions, the greatest salinity values were recorded in austral summer 2012 (February and March), when tidal wave intrusion was recorded up to $6 \mathrm{~km}$ upriver. These conditions remained during 2012, although with a significant variation in salinity values, until decreasing notably in 2014 in greater river streamflow conditions. 


\section{(a) Deep layer}

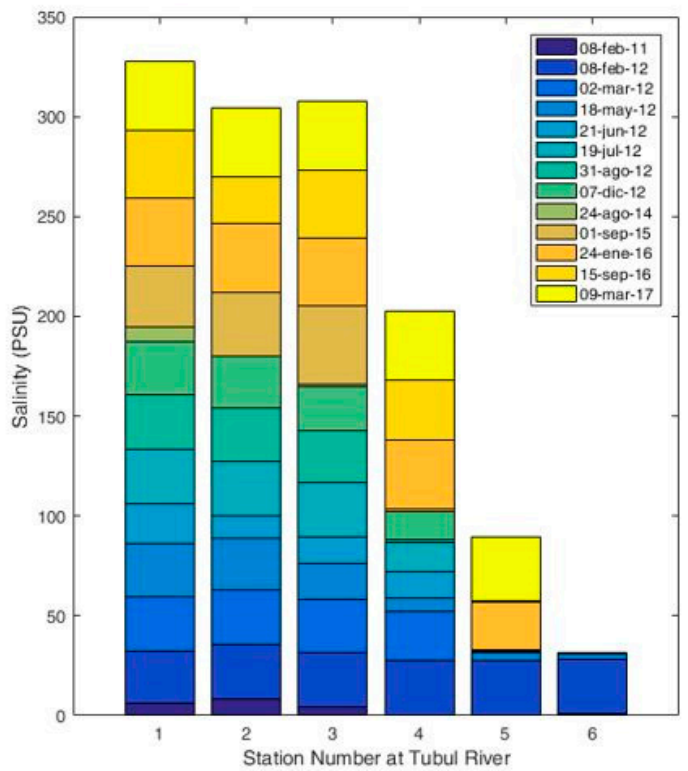

\section{(b) Superficial layer}

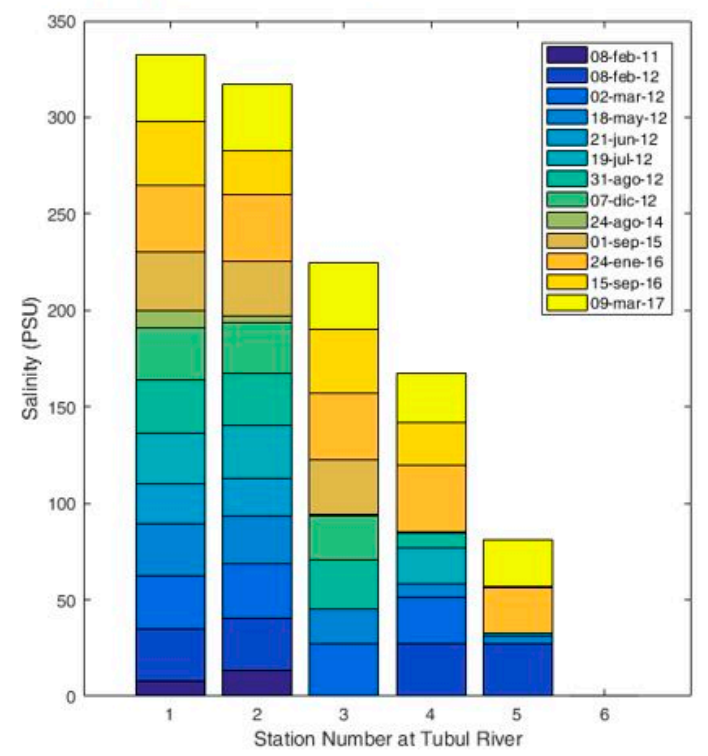

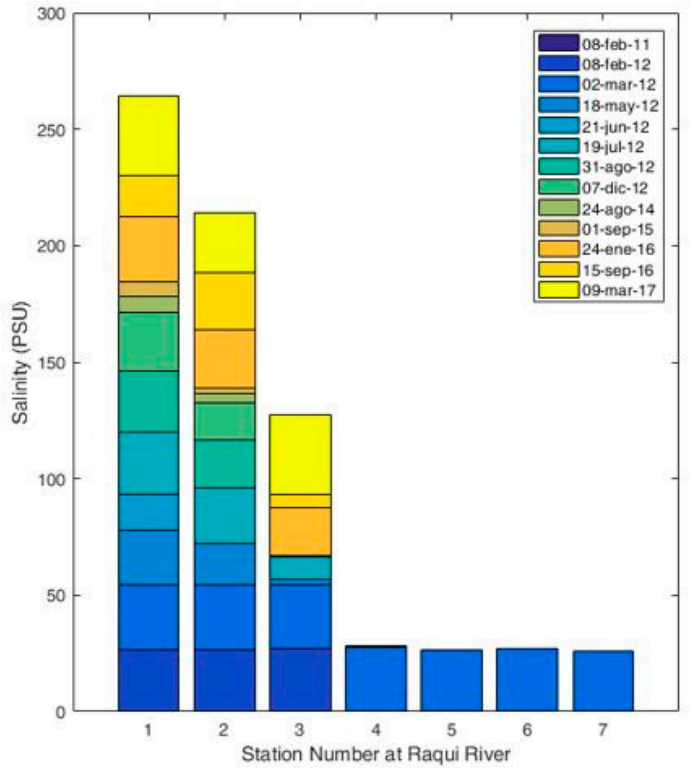

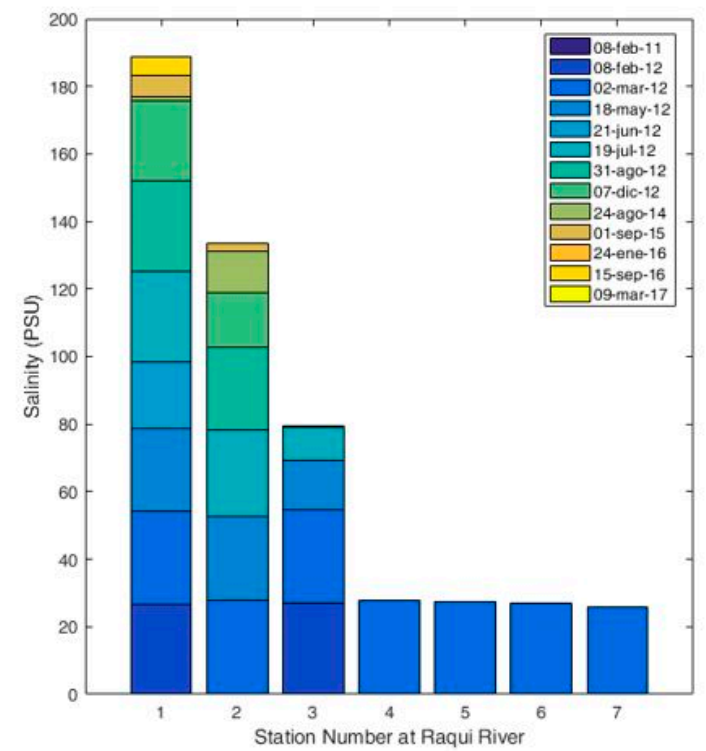

Figure 10. Salinity values (PSU) for postearthquake conditions, Tubul-Raqui wetland. Through the salinity values, shows how the coastal uplift altered the tidal wave intrusion into the interior of the estuary, where minimum values were recorded at most stations (a,b). Even so, this was a short-term effect because, by early 2012, salinity was instrumentally recorded $6 \mathrm{~km}$ upstream in the Tubul River. At stations with a water depth greater than $0.5 \mathrm{~m}$ (Raqui River and stations 3 to 7 in the Tubul River), a slight recovery of marine intrusion was observed over time.

Harmonic analysis of tidal signals shows Courtier's " $\mathrm{F}$ " coefficient values of 0.435 (2011) and 0.404 (2012), indicating a mixed semidiurnal tide regime. The nonharmonic values for pre- and postearthquake conditions were different, with greater depths observed before the earthquake, meaning that the tidal cycle penetrates differently relative to pre2010 conditions in the estuary. 


\subsection{Floristic Studies}

\section{(a) Floristic Composition}

In 2009, we collected a total of 19 plant species, belonging to 10 families. The main species detected correspond to the Poaceae ( $48 \%$, four species), Asteraceae ( $22 \%$, two species), Juncaceae (12\%, three species), and Fabaceae (10\%, two species). Overall, $65 \%$ of the wetland's vegetation cover was composed of native plants and $35 \%$ of introduced plants. Then, in the fieldwork carried out during 2012, we found a total of 26 plant species, belonging to 10 families. The main species detected correspond to the Poaceae ( $31 \%$, five species), Asteraceae (22\%, four species), Fabaceae (14\%, four species), Juncaceae ( $13 \%$, three species), and Cyperaceae ( $9 \%$, three species). Overall, $44 \%$ of the wetland's vegetation cover was composed of native plants and $42 \%$ of introduced plants. Later, during 2014, we collected a total of 25 plant species, belonging to the same 10 families. The main species detected correspond to the Poaceae (31\%, six species), Asteraceae (15\%, three species), Juncaceae (13\%, three species), Cyperaceae (13\%, two species), and Fabaceae ( $8 \%$, three species). Overall, $56 \%$ of the wetland's vegetation cover was composed of native plants and $33 \%$ of introduced plants. Finally, in 2016, we found a total of 31 plant species, belonging to 11 families. The main species detected correspond to the Poaceae ( $44 \%$, nine species), Juncaceae (12\%, three species), Cyperaceae ( $9 \%$, four species), and Fabaceae ( $8 \%$, two species). Overall, $59 \%$ of the wetland's vegetation cover was composed of native plants and $36 \%$ of introduced plants (Supplementary Materials, Table S1 and Figure 11).

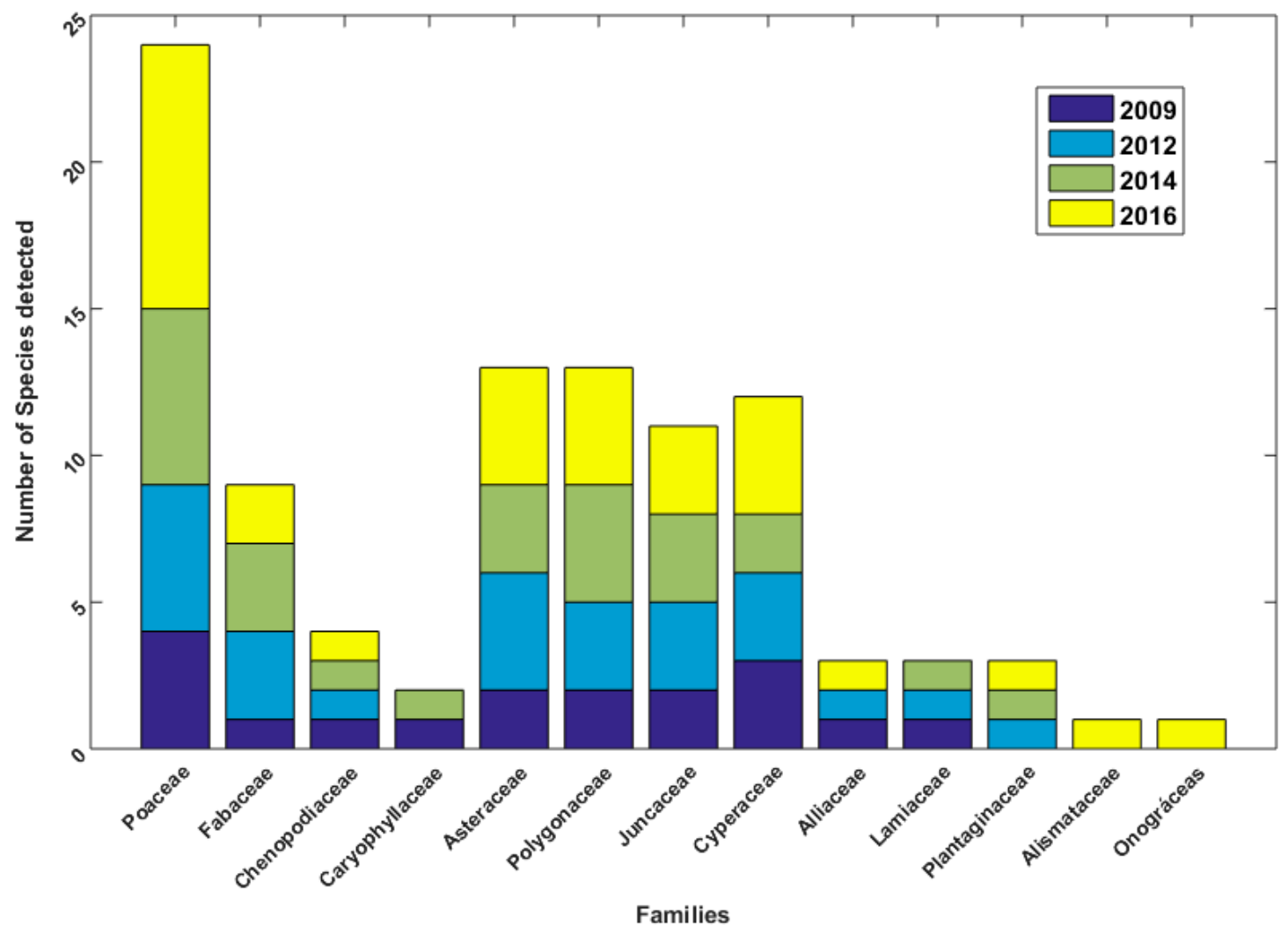

Figure 11. Specific richness by plant family detected in the samplings carried out during 2009 (blue), 2012 (light blue), 2014 (green), and 2016 (yellow).

Most of the collected flora was of herbaceous habit, mostly hemicryptophytes and chamaephytes, which confers ideal attributes for resisting the salinity stress of the saltmarsh and poor drainage. 


\section{(b) Vegetation Structure}

The vegetation structure of the Tubul-Raqui wetland is constituted by nonarboreal emergent communities of vascular plants, with roots that occur in areas in which salinity range from very high (26 PSU) near the saltmarsh to very low (1 PSU) in higher zones, where fresh water dominates, and other zones, where periodic pools generated by tides occur, giving rise to very different geomorphological units according to vegetation type (coastal saltmarsh, floodplain, and palustrine wetlands).

The coastal saltmarsh proved to be extremely homogenous, dominated by the tallgrass Spartina densiflora and with the occasional participation of Sarcocornia fruticosa, both of which adapted to the high salinity of the substrate and surrounding water, an association considered typical of saltmarshes by San Martín et al. [29].

The floodplains were characterized by a greater diversity of plant species. This characteristic depended directly on the lower saline influence in the floodplains and the greater extent of human activity in the area. These factors promoted the establishment of a higher number of plant species, allowing the survival of halophyte species such as Cotula coronopifolia and the introduction of forage species such as Trifolium repens. In addition, depending on the drainage conditions of the plain, it was possible to identify native hydrophilic species such as Scirpus californicus and Juncus procerus.

A general zoning diagram establishes that the peripheral areas of the floodplains and ravines that drain into the wetland are covered by a low Myrtaceae forest, giving rise to an ecotonal zone dominated by a prairie with reeds and rushes, with variable coverage, and a low prairie with Cotula coronopifolia in the salt plains, while the lower portion is composed of a medium-tall grassland of halophyte plants dominated by Spartina densiflora and Sarcocornia fructicosa, which is the only association found without major human interventions due to the extreme characteristics of the habitat.

\section{(c) Diversity}

The Tubul-Raqui wetland presented low vegetation diversity levels (Figure 12). The highest values were presented by the prairie with low drainage (station 3) in 2009 and (stations 3, 4, 5, and 7) in 2012, 2014, and 2016, where the greater number of exotic species increased diversity levels. The palustrine wetland (station 9) also stands out, with abundant hydrophilic species during the four years studied. The Spartina densiflora meadow (seasons 1 and 6) presented the maximum dominance value and the minimum diversity value, representing a community dominated by few species. These results were observed during the years 2009, 2012, and 2014. Subsequently, the 2016 sampling presented diversity and dominance values similar to those mentioned above, in stations 1, 6, 8, and 10, all corresponding to Spartina densiflora meadows. (Figure 12).

\section{(d) Conservation Status}

The Tubul-Raqui wetland did not present species with conservation problems since many of them are widely distributed in other saltmarsh and palustrine wetland systems $[29,60,62]$. Human intervention such as livestock activity and farming was observed in the field. Home construction is another reason for which it is practically impossible to find remnants of original vegetation in these areas, with the best-conserved community being the Spartina-Sarcocornia association in the lower portion of the wetland since the habitat conditions impede its use by humans.

\subsection{Numerical Modeling Results}

The numerical modeling results show the change in the morphological response of the sector before and after the coseismic movements on 27 February 2010. Two types of responses can be observed, the beach response to regular waves and the beach response to storm waves.

\section{(a) Regular Waves}


The modeling results for regular wave conditions, distinguished between winter and summer, do not show large differences between the seasons. However, when the uplift of $1.4 \mathrm{~m}$ in the area [95] is incorporated, the changes in the accretion and erosion patterns of the areas can be clearly identified (see Figure 13).
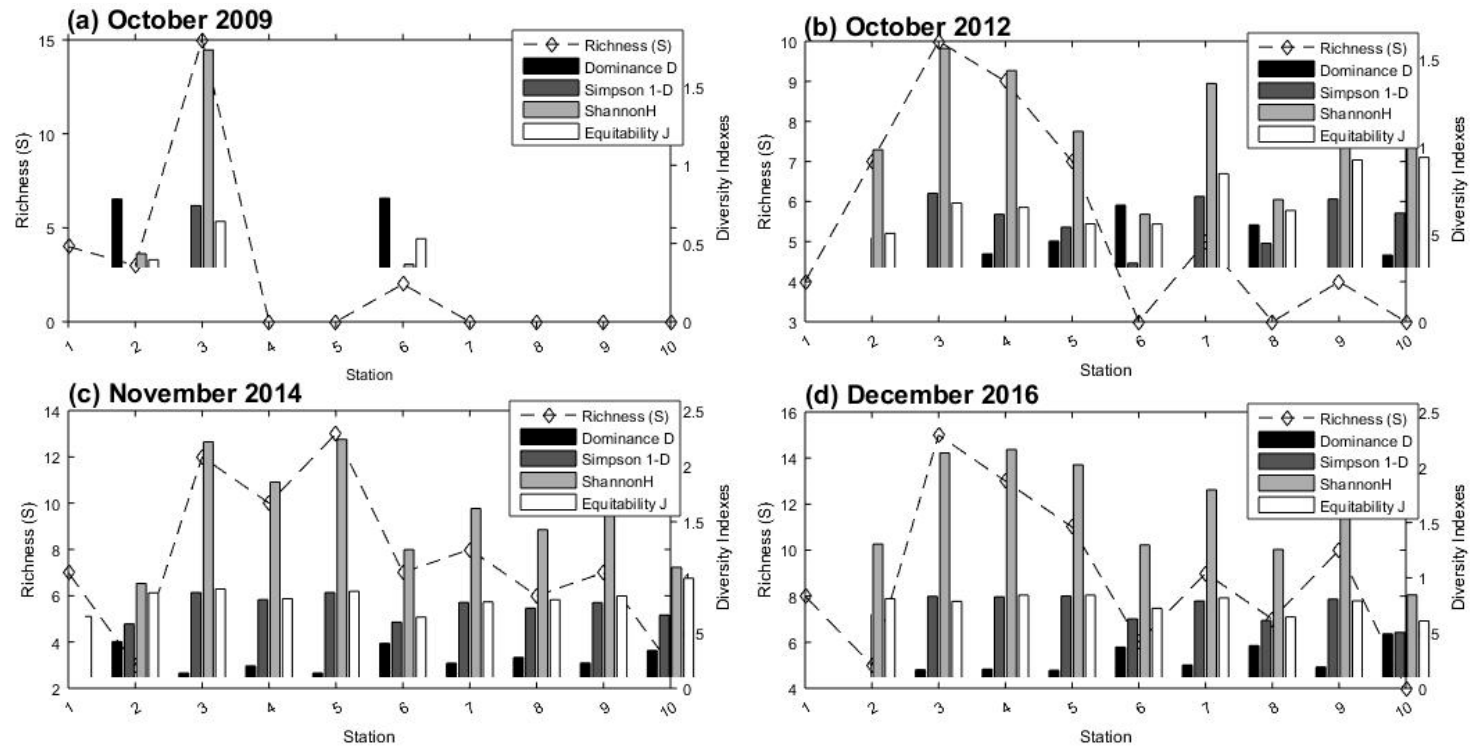

Figure 12. Diversity indices (richness, abundance, $\mathrm{S}^{\prime}$ and $\mathrm{H}^{\prime}$ diversity, dominance (D), and evenness (J)) for: (a) sampling stations 2009, (b) sampling stations 2012, (c) sampling stations 2014 and (d) sampling stations 2016. The floristic and vegetation comparison between the pre-earthquake (2009) and postearthquake (2012) periods did not present great differences.

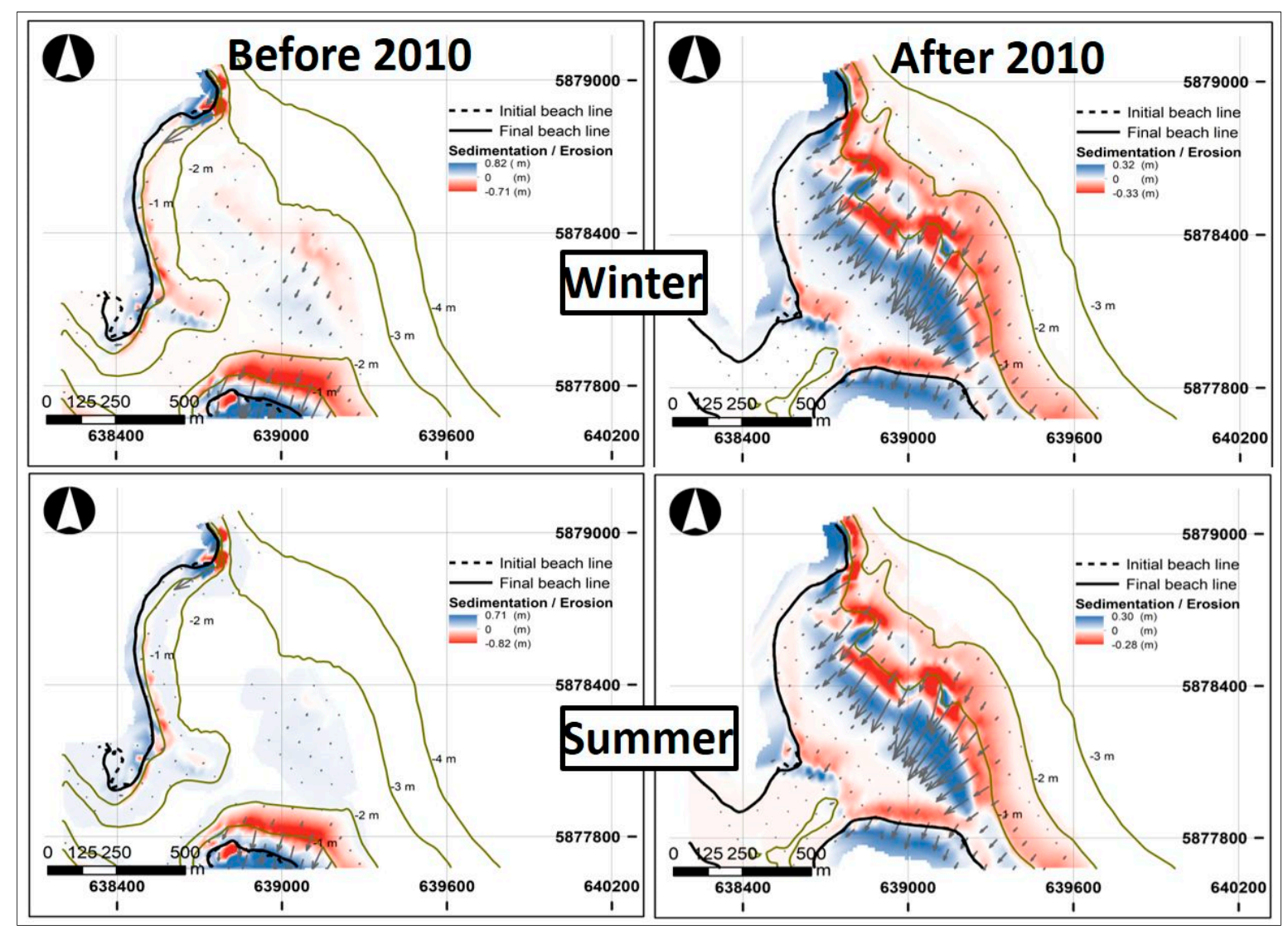

Figure 13. Morphological response of Tubul Beach before and after the 2010 earthquake (uplift of $1.4 \mathrm{~m}$ ): upper left, before 2010, winter waves; lower left, before 2010, summer waves; upper right, after 2010, winter waves; lower right, after 2010, summer waves. 
One of the main changes that can be observed is a certain accretion trend that can be directly observed at the mouth of the wetland, which tends to close and thus decrease the tidal exchange of the wetland.

Another observation from the obtained results is related to a clear recovery of the intermediate part of the beach from sediment originating in deeper water, as can be observed in Figure 14, which shows that the strongest erosion occurred in deep water areas. This change, if extrapolated over time, will tend to form a wider beach with a lower slope than the beach before 27 February 2010.
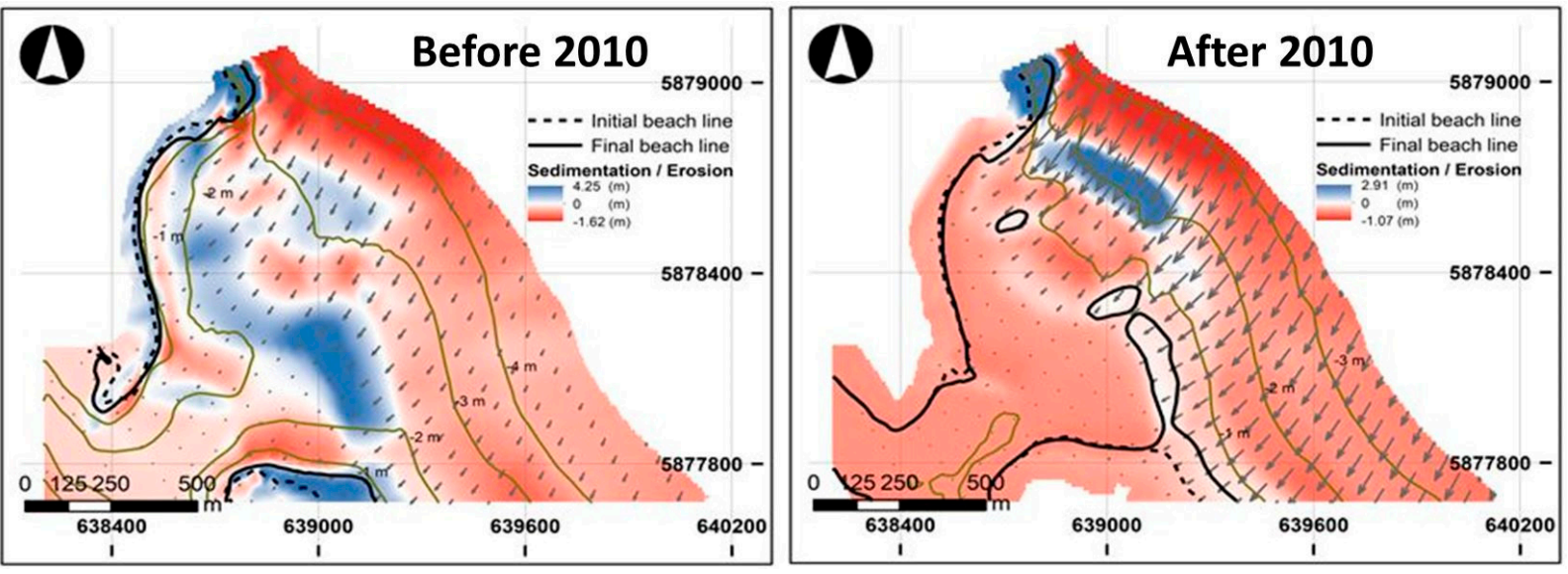

Figure 14. Morphological response of Tubul Beach before and after the 2010 earthquake for storm wave conditions.

\section{(b) Storm waves}

The changes observed for storm waves (Figure 14) are very significant for both conditions (pre- and postearthquake). This is because the initial beach profile for the calculations was the equilibrium profile for regular wave conditions. However, important differences in the evolution of the beach are observed in each case, heavily increasing the eroded zone in the post-2010 condition. It is also observed that the previous condition did not generate major erosion beyond the coastline since the line is somehow in equilibrium for storm conditions, but it did generate greater sedimentation in the mouth that tended to block the tidal exchange to and from the wetland. Furthermore, the new bathymetric scenario created following 27 February 2010 with the subsidence requires a greater amount of sediment from the coast to balance the storm wave energy, which generates a reset of the wetland mouth and is perceived as large erosion areas, but the zones located on the eastern part of the mouth remain little altered.

\section{Discussion}

Large-magnitude natural disturbances such as earthquakes and tsunamis are recurring phenomena on the Chilean coast. This historical recurrence has been well documented, with evidence of events that have been classified as gigantic due to their magnitudes $(\mathrm{M} \geq 9.0)$ [96-99]. The last major earthquake ( $\mathrm{Mw}=8.8$ in 2010) heavily affected the Tubul-Raqui area and the entire coast near the southern rupture segment $[46,51]$. Since Tubul-Raqui is a coastal wetland, the effects were varied, affecting the morphology, tidal wave intrusion, and biota. The types of changes undergone in this wetland, according to the collected data, can be interpreted as a function of three principal aspects:

(a) Geomorphological Changes and Marine Intrusion Effects

Microtidal estuarine environments such as Tubul are characterized by a significant natural variability of forms; however, the role played by earthquakes and tsunamis in this variability on medium- and short-term scales is little understood [19]. Two towns on this coast—Lebu and Tubul—have been affected by significant coastal uplift generated by the 
27 February 2010 earthquake, which has allowed an understanding of the postearthquake recovery process. In the case of the first, the uplift was $1.4 \mathrm{~m}$, which increased the width of the intertidal zone of the beach by $100 \mathrm{~m}[51,100]$. However, this did not change the position of the shoreline, and thus, during the last 36 years, the shoreline of the Tubul-Raqui wetland presented a mean retreat rate of $-1.32 \mathrm{~m} /$ year. Meanwhile, the Lebu pocket beach $\left(37^{\circ} \mathrm{S}\right)$, affected by an uplift of $1.7 \mathrm{~m}$, presented a mean accretion rate of $2.80 \mathrm{~m} /$ year in the 1984-2014 period. Here, there was a rapid recovery of the prior morphodynamic characteristics of the beach [19].

The differences in the mean rates of change in the towns of Tubul and Lebu can be explained by the greater uplift caused by the 1960 earthquake in Lebu. On the northern shore of the Arauco Peninsula, the 1960 earthquake generated an uplift of $0.4 \mathrm{~cm}$ [101]. The towns of Lebu, Llico, Punta Lavapié, and Tubul, located closer to the trench, underwent greater interseismic subsidence, with which the shoreline tends to recede due to the ensuing erosion process [95]. In Tubul, an area affected by interseismic subsidence, the predominant process is erosion generated by tectonic processes that naturally induce shoreline retreat. The coseismic movements in this area have not allowed the wetland to compensate for the erosion process, in contrast to what occurred in Lebu as a result of the coastal uplift of 1960 and 2010.

This uplift caused a significant geomorphological change in the wetland upon interrupting tidal wave intrusion and resulting in the drying of the saltmarsh. As indicated by the collected data, the tide was impeded for almost a year, and subsequently, its entry was weak, according to the reported salinity data. Other studies also indicate that tidal wave intrusion was partially recovered 10 months after the earthquake, especially within three kilometers of the mouth, although with values lower than those recorded before the earthquake [48]. Starting in 2012, the salinity values were greater and comparable to those recorded before the earthquake [48]. In December 2008, salinity values of up to $32.2 \mathrm{PSU}, 4 \mathrm{~km}$ from the mouth of the Tubul River, and 31 PSU, $8 \mathrm{~km}$ from it, were recorded [48]. These values are high and expected in the summer period with low river streamflows since both rivers have an entirely pluvial regime. The tidal wave entry capacity before the earthquake was high, with direct influence up $10 \mathrm{~km}$ upstream in both rivers $[48,61]$.

In this investigation, the maximum recorded value was 27.3 PSU in summer (February 2012), $8 \mathrm{~km}$ upstream in the Tubul River. In the Raqui River, the maximum recorded salinity value was 27.9 PSU (station 4), $6 \mathrm{~km}$ upstream, also in summer conditions (March 2012).

(b) Changes in Floristic Composition and Vegetation Structure

Ecosystems are generally defined based on the plant species and principal characteristics of the site. The composition and structure of plant communities are a fundamental basis for determining the current conservation status and potential changes in restoration or conservation processes in an area [102].

The coastal saltmarsh and floodplains of the Tubul-Raqui area have different floristic compositions, a phenomenon explained by changes in salinity gradients and human disturbance. In the saltmarsh perennial species dominated, mostly halophytes, although there were others with a wide distribution without this trait [103]. The low number of species able to tolerate the high salinity of these ecosystems results in rather homogenous vegetation $[103,104]$, with the native Poaceae Spartina densiflora, responsible for the formation of prairies or esparto fields, predominating. This species is of fundamental importance in these ecosystems, acting as an engineer species because it models and stabilizes the riverbanks against the effects of the tides and is the main energy source in the wetland, supplying large quantities of organic detritus that enter aquatic and terrestrial food chains [9].

However, in some sectors, it was also possible to find the succulent halophyte Sarcocornia fruticosa, which has been observed in other areas in association with Spartina densiflora [105], giving rise to complex vegetation mosaics called Sarcocornio—Spartinentum densiflorae [29], with Spartina densiflora 
much more abundant than the latter [106]. These areas are also characterized by little human intervention since there is no agriculture or livestock activity.

The proportion of native taxa was greater in undisturbed areas, in zones dominated by coastal saltmarshes where high salinity levels and extreme environmental conditions impede the proliferation of invasive plants and their use by humans; however, the greatest species diversity was observed in disturbed areas where introduced taxa contribute in large measure to species richness. The plant associations present in the Tubul-Raqui wetland are similar to those of other saltmarsh systems in south-central Chile [60-62].

The Tubul-Raqui wetland, similar to other saltmarshes of southern Chile, presents low levels of vegetation diversity [60], and the plant species there do not present conservation problems since they are widely distributed in other coastal wetlands; however, the various human activities such as livestock, agriculture and home construction have replaced the original vegetation of the floodplains and areas with lower salinity [49].

The vegetation structure comparison between the pre-earthquake (2009) and postearthquake (2012, 2014, and 2016) periods did not show differences, since all the stations analyzed remained without relevant vegetation changes. However, it is possible to observe slight changes in the wetland's floristic composition, mainly marked by a decrease in native flora from $65 \%$ during 2009 to $44 \%$ by 2012 , followed by an increase in native plant species to $57 \%$ during 2016. These results suggest that the Tubul-Raqui wetland, although severely affected by the coastal uplift resulting from the 27 February 2010 earthquake, has gradually recovered, exhibiting no evidence of damage at the analyzed stations. It bears mentioning that this is the case only from a vegetation perspective and is probably due to the high tolerance to major environmental changes presented by the halophyte Spartina densiflora, which is very important in the physical, chemical, and biological balance and structuring of this ecosystem [49]

Among wetlands on other tectonic coasts, the Copper River wetland (Alaska), affected in 1964 by an $\mathrm{M}=8.4$ earthquake that generated an uplift between $1.8 \mathrm{~m}$ and $3.4 \mathrm{~m}$ above the previous sea level, stands out. According to Thilenius [15], this uplift had a major impact on the ecosystem since the subtidal zones converted to in-tertidal zones; however, five years after the event, the nature of the taxa and vegetation structure, only was affected with slight changes in the location and abundance of plants.

In the Tubul-Raqui wetland, the vegetation structure as a foundation for a community of specialized organisms adapted to salinity gradients reacted differently to the coastal uplift caused by the earthquake, since its taxa were less affected and its recovery was faster once the tidal wave intrusion was restored. The foregoing coincides with the description of Valdovinos et al. [48], who established that the broad saline meadows or esparto fields dominated by Spartina densiflora did not present signs of having been affected by coastal uplift one year after the earthquake, which is important because it is a fundamental species in the structure of the wetland. According to the authors, this species stabilizes recent sediment deposits and contributes to the maintenance of significant biological diversity.

However, Valdovinos et al. $[48,49,53]$ established that while there was not a significant impact on the coverage of the dominant species of the wetland (Spartina densiflora), there was significant damage to benthic invertebrates due to the drying of and lack of saline intrusion in the saltmarsh, especially the bivalve Ensis macha (navajuela) and Kingiella chilenica, the latter of which is endemic. Ten months after the earthquake, an intense recolonization of amphipods and Polychaeta in undried wetland channels was observed. In addition, the newly emerged beds were recolonized by vegetation and there was a return to the pre-earthquake estuarine conditions. Furthermore, Sandoval et al. [52] established that the most tolerant taxa to environmental perturbations (i.e., Diptera, Annelid, and Polychaeta) surpassed pre-earthquake abundance records after just ten months, whereas the most sensitive taxa were not found after the earthquake. Although the ecosystem was severely affected by the earthquake, it still has properties that make it among the most important in the country [53]. 


\section{(c) Changes in Morphological Response Induced by Subsidence}

Despite the changing trends in the wave climate, sediment transport off of the mouth of the Tubul-Raqui wetland was observed to be rather uniform, with a very prominent southwest direction. This homogenizes the wave patterns observed in the study area, reducing the impacts of changes in the main forcings. The shape of the Gulf of Arauco and the location of Tubul Beach at the bottom of the gulf determine the morphological response, as waves, although they come from different directions, reach the beach having undergone numerous bathymetric refraction processes and diffraction at Sta. Maria Island (see Figure 3) [93].

For the analyzed case at Tubul, the morphological changes observed before and after the earthquake are considerable given the uplift of the land: The morphology of the beach clearly went from a condition of quasistatic equilibrium (very little sediment transport for the predominant conditions) to a situation of change, in which a great quantity of sediment is transported from areas farther from the coast to the beach. The new trends of sediment transport increased the width of the beach, causing an eventual blockage of the wetland mouth that had repercussions for the exchange of water within it and the artisanal fishing activities of the nearby communities.

Due to the lack of obvious changes in principal forcings and the existence of measurements that indicate erosion conditions on Tubul Beach, it is difficult to suggest reasons for this behavior. The numerical modeling of the geomorphological evolution of the beach before and after 27 February 2010 corroborates that the observed erosion response could be related to the coseismic shifts measured in the sector and a reduction in beach recovery capacity due to heavy storms.

The morphological response of the coastline does not present great seasonal variations; thus, the beach should not vary from historical observations. However, storm waves will cause significant erosion in some sectors of the mouth, the repercussions of which will depend on the actual availability of sediment transported by the longshore drift toward the W-SW. The construction of new infrastructure (after 27 February 2010) at the northeast side of the beach that took place as part of the reconstruction process to provide greater functionality to the fisherman's cove could interrupt the normal flow of sediment and alter the sedimentary dynamics of the area, possibly bringing about as yet unknown consequences for the hydrodynamics of the wetland, which must be assessed to prevent further damage to its biota. Although the ecosystem was severely affected by the earthquake, it has maintained the properties that make it one of the most important coastal wetlands in the country.

In addition, since 2015, the Chilean coast has been affected by intense, recurrent storm surges, which have caused drastic morphological changes to numerous sandy shores and severe damage to coastal infrastructure $[107,108]$. Recent research has established a direct relationship between warm ENSO phases and the recurrence and intensity of storm surges, and that amid the scenario of an 8.5 emissions climate change, they will continue to affect the Chilean coast [107]. This has resulted in $80 \%$ of beaches in Chile undergoing a significant erosion process, possibly triggered by storm surges but certainly also by anthropogenic factors [109].

\section{The Chilean Coast in Crisis: Guidelines for Integrated Management}

Given the tectonic context of the Chilean coast and the predicted climate change scenario, having guidelines that allow decisions to be grounded in territorial planning and integrated coastal zone management is a priority. Unfortunately, similar to many countries in other parts of the world, Chile does not have concrete instruments that allow land uses to be planned according to the evolutionary dynamics of the coast and climate change scenarios to be included. The most recent studies on vulnerability to climate change on the Chilean coast establish that the increase in sea level will be important in the coming 15 years and that extreme events associated with storm surges will continue to recur over the next 45 years (IPCC 8.5 emissions scenario) [110]. In addition, experiences with 
reconstruction processes in the last 10 years show a high social and economic cost, with at least 13 reconstruction processes having taken place after tsunamigenic earthquakes, mudslides, and volcanic eruptions that have affected the coast. In particular, research on the reconstruction process following the earthquake and tsunami of 27 February 2010 has established that it has promoted the development of new risk areas instead of an effective risk reduction, considering the great opportunity such activities present to increase the social and urban resistance of the affected areas [59,111,112].

In this context, and amid the dramatic reduction in marine coastal ecosystems in the country, particularly due to urbanization and urban growth [113,114], a coast law in Chile is being pushed for [100]. Among the criteria proposed in this law are disaster risk reduction and integrated coastal management focused on human welfare sustainability (HWS) and ecosystem-based management. The consideration of the precautionary principle, environmental justice, and the recognition of the public nature of the coast are also important [115]. These efforts, while medium or long term, will allow the foundations to be laid for future governance focused on sustainable development.

Given the strong tectonic control of the Chilean coast and the urgent need to adapt to climate change, the main challenges to increasing coastal resilience and sustainability are closely linked to the geomorphic adaptation of estuaries to new streamflow conditions and forcings and the dynamic response of intertidal vegetation communities. Indeed, resilient ecosystems require a rigorous, science-informed coastal planning approach, implemented at the appropriate time scale [27]. To achieve this, the decision-making process for estuaries requires extensive interdisciplinary studies such as that presented in this paper. Only by analyzing the implications for hydrodynamics and morphodynamics, as well as ecological, biogeochemical, and dependent processes, can uncertainties be reduced, enhancing the predictive ability of models to provide management advice [28] and improving the quality of the measures that are implemented. The effectiveness of these measures relies on the scientific effort to understand each system and on the political will to translate scientific language into the language of public policies and methodological decision-making processes [116].

\section{Conclusions}

The Tubul-Raqui wetland presents an erosive trend of -1.32 m/year (1979-2015), facilitated by tectonic factors (interseismic subsidence). This process could be increased by anthropogenic factors capable of producing alterations in the sedimentary balance of the estuary.

The recovery of the salt wedge was fast, even considering a large-magnitude coseismic uplift $(1.4 \mathrm{~m})$. A year after the event, the saline intrusion was recorded up to the first $3 \mathrm{~km}$, and two years after, it reached $10 \mathrm{~km}$, returning to pre-earthquake conditions. The foregoing statement establishes the high resilience of these environments to violent geomorphological changes. The effects of the 2010 earthquake and tsunami, despite the ecological damage, especially to benthic macrofauna, did not significantly affect the floristic composition and vegetation structure of the wetland.

The Tubul Beach, located east of the estuary mouth, currently presents erosive behavior and induces vulnerability in the system since its sediment dynamics directly affect the hydrodynamics of the Tubul-Raqui wetland. The sediment transport trends have the potential to block the flow exchange at the mouth of the estuary, with consequences for the physical and biological environment and social implications for the fishing community. Moreover, human interventions in the area such as the construction of a new dock on the western beach could further affect the littoral dynamics of the area.

The increasing urbanization that coastal areas have undergone in recent decades and current trends in climate change highlight the need for a better interdisciplinary understanding of coastal areas to achieve more sustainable and resilient natural systems [58]. It is a priority to know how the coastline changes and recovers after a high-impact natural 
disturbance to contribute to a paradigm shift toward more integrated and holistic coastal zone management.

Supplementary Materials: The following are available online at https:/ /www.mdpi.com/article/ $10.3390 / w 13111467 /$ s1, Table S1. Taxonomic composition of the vegetation in pre- (2009) and postearthquake (2012, 2014 and 2016) conditions in the Tubul-Raqui wetland. ( $0=$ Absence; $1=$ Presence $)$ ( $\mathrm{E}=$ Exotic; $\mathrm{N}=$ Native; $\mathrm{C}=$ Cosmopolitan).

Author Contributions: Conceptualization, C.M.; methodology, C.M., E.S.-Z., and M.V.; sampling, C.M., E.S.-Z., and O.R.; data statistics, M.V. and M.G.; preparing maps and figures, P.L.; writingoriginal draft preparation, C.M., E.S.-Z., and O.R.; funding acquisition C.M. and C.R. All authors have read and agreed to the published version of the manuscript.

Funding: This research was funded by the FONDECYT N1200306, N1190251, FONDAP N 15110017 grants from the Agencia Nacional de Investigación y Desarrollo (ANID) of Chile and ANID/Millennium Science Initiative Program-ICN2019_015. Mauricio Villagrán was partially funded by UCSC-FAA $02 / 2018$ project.

Institutional Review Board Statement: Not applicable.

Informed Consent Statement: Not applicable.

Data Availability Statement: The data presented in this study may be available in a redacted form on request from the corresponding author.

Conflicts of Interest: The authors declare no conflict of interest. The funders had no role in the design of the study; in the collection, analyses, or interpretation of data; in the writing of the manuscript, or in the decision to publish the results.

\section{References}

1. Mitsch, W.; Gosselink, J. Wetlands, 3rd ed.; John Wiley \& Sons, Inc.: New York, NY, USA, 2000.

2. Wall, D.H.; Palmer, M.A.; Snelgrove, P.V.R. Biodiversity in critical transition zones between terrestrial, freshwater, and marine soils and sediments: Processes, linkages, and management implications. Ecosystems 2001, 4, 418-420. [CrossRef]

3. Atwater, B.F. Evidence for Great Holocene earthquakes along the outer coast of Washington State. Science 1987, 236, 942-944. [CrossRef]

4. Atwater, B.; Nunez, H.; Vita-Finzi, C. Net late Holocene emergence despite earthquake-induced submergence, South-central Chile. In Impacts of Tectonics on Quaternary Coastal Evolution, Quaternary International; Ota, Y., Nelson, A.R., Berryman, K.R., Eds.; Pergamon: Oxford, UK, 1992; Volume 15/16, pp. 77-85.

5. Ota, Y.; Paskoff, F. Holocene deposits on the coast of the North-Central Chile: Radiocarbon ages and implications for coastal changes. Rev. Geol. Chile 1993, 20, 25-32.

6. Clague, J.J.; Bobrowsky, P.T. Evidence for a large earthquake and tsunami 100-400 years ago on Western Vancouver Island, British Columbia. Quat. Res. 1994, 41, 176-184. [CrossRef]

7. Hemphill-Haley, E. Diatom evidence for earthquake-induced subsidence and tsunami $300 \mathrm{yr}$ ago in southern coastal Washington. Geol. Soc. Am. Bull. 1995, 107, 367-378. [CrossRef]

8. Nelson, A.; Shennan, I.; Long, A. Identifying coseismic subsidence in tidal-wetland stratigraphical sequences at the Cascadia subduction zone of western North America. J. Geophys. Res. 1996, 101, 6115-6135. [CrossRef]

9. Soter, S. Holocene uplift and subsidence in the Helike Delta, Gulf of Corinth, Greece. In Coastal Tectonics; Stewart, I.S., Vita-Finzi, C., Eds.; Geological Society Special Publications; Geological Society: London, UK, 1998; Volume 146, pp. 41-56.

10. Peterson, C.D.; Doyle, D.L.; Barnett, E.T. Coastal flooding and beach retreat from coseismic subsidence in the central Cascadia margin, USA. Environ. Eng. Geosci. 2000, 6, 255-269. [CrossRef]

11. Atwater, B.F.; Yamaguchi, D.K.; Bondevik, S.; Barnhardt, W.A.; Amidon, L.J.; Benson, B.E.; Skjerdal, G.; Shulene, J.A.; Nanayama, F. Rapid resetting of an estuarine recorder of the 1964 Alaska earthquake. GSA Bull. 2001, 113, 1193-1204. [CrossRef]

12. Rhodes, B.P.; Kirby, M.E.; Jankaew, K.; Choowong, M. Evidence for a mid-Holocene tsunami deposit along the Andaman coast of Thailand preserved in a mangrove environment. Mar. Geol. 2011, 282, 255-267. [CrossRef]

13. Troiani, B.; Simms, A.; DellaPenna, T.; Piper, E.; Yokoyama, Y. The importance of sea-level and climate change, including changing wind energy, on the evolution of a coastal estuary: Copano Bay, Texas. Mar. Geol. 2011, 280, 1-19. [CrossRef]

14. Dura, T.; Cisternas, M.; Horton, B.P.; Ely, L.L.; Nelson, A.R.; Wesson, R.L.; Pilarczyk, J.E. Coastal evidence for Holocene subduction-zone earthquakes and tsunamis in central Chile. Quat. Sci. Rev. 2015, 113, 93-111. [CrossRef]

15. Thilenius, J. Phytosociology and Succession on Earthquake-Uplifted Coastal Wetlands, Copper River Delta, Alaska; Gen. Tech. Rep. PNW-GTR-346; Department of Agriculture, Forest Service, Pacific Northwest Research Station: Portland, OR, USA, 1995; 58p. 
16. Paris, R.; Wassmer, P.; Sartohadi, J.; Lavigne, F.; Barthomeuf, B.; Desgages, E.; Grancher, D.; Baumert, P.; Vautier, F.; Brunstein, D.; et al. Tsunamis as geomorphic crises: Lessons from the December 26, 2004 tsunami in Lhok Nga, West Banda Aceh (Sumatra, Indonesia). Geomorphology 2009, 104, 59-72. [CrossRef]

17. Reinhardt, E.; Nairn, R.; López, G.I. Recovery estimates for the Río Cruces after the May 1960 Chilean earthquake. Mar. Geol. 2010, 269, 18-33. [CrossRef]

18. Kaminsky, G.M.; Ruggiero, P.; Buijsman, M.C.; McCandless, D.; Gelfenbaum, G. Historical evolution of the Columbia River littoral cell. Mar. Geol. 2010, 273, 96-126. [CrossRef]

19. Martínez, C.; Rojas, D.; Quezada, M.; Quezada, J.; Oliva, R. Post-earthquake coastal evolution and recovery of an embayed beach in central-southern Chile. Geomorphology 2015, 250, 321-333. [CrossRef]

20. Ioualalen, M.; Pelinovsky, E.; Asavanant, J.; Lipikorn, R.; Deschamps, A. On the weak impact of the 26 December Indian Ocean tsunami on the Bangladesh coast. Nat. Hazards Earth Syst. Sci. 2007, 7, 141-147. [CrossRef]

21. Vita-Finzi, C. Neotectonics and the 2004 and 2005 earthquake sequences at Sumatra. Mar. Geol. 2008, 248, 47-52. [CrossRef]

22. Jiménez, J.; Sancho-García, A.; Bosom, E.; Valdemoro, E.; Guillén, J. Storm-induced damages along the Catalan coast (NW Medi-terranean) during the period 1958-2008. Geomorphology 2012, 143, 24-33. [CrossRef]

23. Løvholt, F.; Glimsdal, S.; Harbitz, C.B.; Horspool, N.; Smebye, H.; de Bono, A.; Nadim, F. Global tsunami hazard and exposure due to large co-seismic slip. Int. J. Disaster Risk Reduct. 2014, 10, 406-418. [CrossRef]

24. Masselink, G.; Castelle, B.; Scott, T.; Dodet, G.; Suanez, S.; Jackson, D.; Floc'h, F. Extreme wave activity during 2013/2014 winter and morphological impacts along the Atlantic coast of Europe. Geophys. Res. Lett. 2016, 43, 2135-2143. [CrossRef]

25. Carvajal, M.; Contreras-López, M.; Winckler, P.; Sepúlveda, I. Meteotsunamis occurring along the Southwest Coast of South America during an intense storm. Pure Appl. Geophys. 2017, 174, 3313-3323. [CrossRef]

26. Valderrama-Landeros, L.H.; Martell-Dubois, R.; Ressl, R.; Silva-Casarín, R.; Cruz-Ramírez, C.J.; Muñoz-Pérez, J.J. Dynamics of coastline changes in Mexico. J. Geogr. Sci. 2019, 29, 1637-1654. [CrossRef]

27. Masselink, G.; Lazarus, E.D. Defining coastal resilience. Water 2019, 11, 2587. [CrossRef]

28. Khojasteh, D.; Glamore, W.; Heimhuber, V.; Felder, S. Sea level rise impacts on estuarine dynamics: A review. Sci. Total. Environ. 2021, 780, 146470. [CrossRef]

29. San Martín, C.; Contreras, D.; San Martín, J.; Ramírez, C. Vegetación de las marismas del centro-sur de Chile. Rev. Chil. Hist. Nat. 1992, 65, 327-342. (In Spanish)

30. Valdovinos, C. Caracterización ambiental del Estuario Lenga, VIII Región, Chile. In Planificación y Gestión de la Zona Costera; Análisis de un caso: Lenga Concepción; EULA-Universidad de Concepción: Concepción, Chile, 1993. (In Spanish)

31. Quintana, V. Caracterización florística y faunística de un humedal costero de la VIII región, el caso del Estero Lenga. In PlanifiCación y Gestión de la Zona Costera; Análisis de un caso: Lenga; Serie: Propuesta de Ordenamiento 8; Centro EULA-Universidad de Concepción: Concepción, Chile, 1993; pp. 41-56. (In Spanish)

32. Ramírez, C.; San Martín, C.; Rubilar, H. Una propuesta para la clasificación de humedales chilenos. Rev. Geogr. Valpso. 2002, 32, 265-273. (In Spanish)

33. Hauenstein, E.; Gonzalez, M.; Peña-Cortés, F.; Muñoz-Pedreros, A. Clasificacion y caracterizacion de la flora y vegetacion de los humedales de la Costa de Tolten (IX Region, Chile). Gayana. Bot. 2002, 59, 87-100. (In Spanish) [CrossRef]

34. González, A.; Victoriano, P. Aves de los humedales costeros de la zona de Concepción y alrededores. In Historia, Biodiversidad y Ecología de los Bosques Costeros de Chile; Smith-Ramírez, C., Armesto, J., Valdovinos, C., Eds.; Editorial Universitaria: Santiago, Chile, 2005; pp. 485-497. (In Spanish)

35. Hauenstein, E.; González, M.; Peña-Cortés, F.; Muñoz-Pedreros, A. Diversidad vegetal en humedales costeros de la región de la Araucanía. In Historia, Biodiversidad y Ecología de los Bosques Costeros de Chile; Smith-Ramírez, C., Armesto, J., Valdovinos, C., Eds.; Editorial Universitaria: Santiago, Chile, 2005; pp. 197-205. (In Spanish)

36. Comisión Nacional de Medio Ambiente. Estrategia Para la Conservación y Uso Racional de los Humedales en Chile; CONAMA: Santiago, Chile, 2005. (In Spanish)

37. Peña-Cortés, F.; Gutiérrez, P.; Rebolledo, G.; Escalona, M.; Hauenstein, E.E.; Bertrán, C.; Tapia, J. Determinación del nivel de antro-pización de humedales como criterio para la planificación ecológica de la cuenca del lago Budi, IX región de la Araucanía, Chile. Rev. Geogr. Norte Gd. 2006, 36, 75-91. (In Spanish)

38. Villagrán, R.; Aguayo, M.; Parra, L.; González, A. Relación entre características del hábitat y estructura del ensamble de insectos en humedales palustres urbanos del centro-sur de Chile. Rev. Chil. Hist. Nat. 2006, 79, 195-211. (In Spanish) [CrossRef]

39. Smith, P.; Romero, H. Efectos del crecimiento urbano del Área Metropolitana de Concepción sobre los humedales de RocuantAndalién, Los Batros y Lenga. Rev. Geogr. Norte Gd. 2009, 43, 81-93. (In Spanish)

40. Sepúlveda, E.; Parra, L.; Benítez, H.; Rojas, C. Estados de naturalidad y heterogeneidad vegetacional de humedales palustres y su efecto sobre la diversidad de Macrolepidoptera (Insecta: Lepidoptera). SHILAP Rev. Lepidopterol. 2012, 40, 155-170. (In Spanish)

41. Catálan, P.A.; Cienfuegos, R.; Villagran, M. Perspectives on the long-term equilibrium of a wave dominated coastal zone affected by tsunamis: The case of Central Chile. J. Coast. Res. 2014, 71, 55-61. [CrossRef]

42. Marín, A.; Gelcich, S.; Araya, G.; Olea, G.; Espíndola, M.; Castilla, J.C. The 2010 tsunami in Chile: Devastation and survival of coastal small-scale fishing communities. Mar. Policy 2010, 34, 1381-1384. [CrossRef]

43. Morton, R.A.; Gelfenbaum, G.; Buckley, M.L.; Richmond, B.M. Geological effects and implications of the 2010 tsunami along the central coast of Chile. Sediment. Geol. 2011, 242, 34-51. [CrossRef] 
44. Quezada, J.; Jaque, E.; Belmonte, A.; Fernández, A.; Vásquez, D.; Martínez, C. Movimientos cosísmicos verticales y cambios geo-morfológicos generados durante el terremoto $\mathrm{Mw}=8,8$ del 27 de Febrero de 2010 en el Centro-Sur de Chile. Rev. Geogr. Sur. 2010, 1, 11-45. (In Spanish)

45. Farias, M.; Vargas, G.; Tassara, A.; Carretier, S.; Baize, S.; Melnick, D.; Bataille, K. Land-level changes produced by the $2010 \mathrm{Mw}$ 8.8 Chile earthquake. Science 2010, 329, 916. [CrossRef] [PubMed]

46. Fritz, H.; Petroff, C.; Catalan, P.; Cienfuegos, R.; Winckler, P.; Kalligeris, N.; Weiss, R.; Barrientos, S.; Meneses, G.; Valderas-Bermejo, C.; et al. Field survey on the 27 February 2010 Chilean Tsunami. Pure Appl. Geophys. 2011, 168, 1989-2010. [CrossRef]

47. Martínez, C.; Rojas, O.; Jaque, E.; Quezada, J.; Vásquez, D.; Belmonte, A. Efectos territoriales del tsunami del 27 de Febrero de 2010 en la costa de la Región del Biobío. Rev. Geogr. Am. Cent. 2011, 2, 1-16. (In Spanish)

48. Valdovinos, C.; Sandoval, N.; Vásquez, D.; Olmos, V. El humedal costero Tubul-Raqui: Un ecosistema chileno de alto valor de conservación severamente perturbado por el terremoto del 2010. In Humedales Costeros de Chile: Aportes Científicos a su Gestión Sustentable; Camaño, A., Fariña, J., Eds.; Ediciones Universidad Católica de Chile: Santiago, Chile, 2012; pp. 391-437. (In Spanish)

49. Valdovinos, C.; Muñoz, M.; Sandoval, N.; Vásquez, D.; Olmos, V. Desastres naturales y biodiversidad: El caso del humedal costero Tubul-Raqui. Rev. Soc. Hoy 2010, 19, 33-51. (In Spanish)

50. Martínez, C.; Quezada, M.; Rubio, P. Historical changes in the shoreline and littoral processes on a headland bay beach in central Chile. Geomorphology 2011, 135, 80-96. [CrossRef]

51. Vargas, G.; Farías, M.; Carretier, S.; Tassara, A.; Baize, S.; Melnick, D. Coastal uplift and tsunami effects associated to the $2010 \mathrm{Mw}$ 8.8 Maule earthquake in Central Chile. Andean Geol. 2011, 38, 219-238.

52. Sandoval, N.; Valdovinos, C.; Oyanedel, J.P.; V'asquez, D. Impacts of coseismic uplift caused by the $20108.8 \mathrm{Mw}$ earthquake on the macrobenthic community of the Tubul-Raqui Saltmarsh (Chile). Estuar. Coast. Shelf Sci. 2019, 226. [CrossRef]

53. Valdovinos, C.; Sandoval, N.; Vasquez, D.; Olmos, V. The Tubul-Raqui coastal wetland: A Chilean ecosystem of high conservation value severely disturbed by the 2010 earthquake. In The Ecology and Natural History of Chilean Saltmarshes; Fariña, J., Camaño, A., Eds.; Springer: Cham, Switzerland, 2017.

54. Vásquez, D.; Sandoval, N.; Fierro, P.; Valdovinos, C. Morphological impacts of the Chilean megathrust earthquake Mw 8.8 on coastal wetlands of high conservation value. Estuar. Coast. Shelf Sci. 2020, 245, 106922. [CrossRef]

55. Hidalgo, R.; Zunino, H. La urbanización de las áreas periféricas en Santiago y Valparaíso: El papel de las relaciones de poder en el dibujo de la geografía socio-residencial. Rev. EURE 2011, 27, 79-105. (In Spanish) [CrossRef]

56. Salinas, E.; Pérez, L. Procesos urbanos recientes en el Área Metropolitana de Concepción: Transformaciones morfológicas y tipologías de ocupación. Rev. Geogr. Norte Gd. 2011, 49, 79-97. (In Spanish) [CrossRef]

57. Hunt, A.; Watkiss, P. Climate change impacts and adaptation in cities: A review of the literature. Clim. Chang. 2010, 104, 13-49. [CrossRef]

58. Kombiadou, K.; Costas, S.; Carrasco, A.R.; Plomaritis, T.A.; Ferreira, O.; Matias, A. Bridging the gap between resilience and geomorphology of complex coastal systems. Earth-Sci. Rev. 2019, 198, 102934. [CrossRef]

59. Rojas, O.; Saéz, K.; Martínez, C.; Jaque, E. Efectos socioambientales post-catástrofe en localidades costeras vulnerables afectadas por el tsunami del 27/02/2010 en Chile. Interciencia 2014, 39, 383-390. (In Spanish)

60. Ramírez, C.; San Martín, C.; Contreras, D. Ecosociología de las marismas litorales del cetro-sur de Chile. Rev. Agro Sur 1990, 18, 104-112. (In Spanish)

61. Constabel, S. Ambientes Sedimentarios de los Estuarios Tubul y Raqui, VIII Región, Chile. Ph.D. Thesis, Ciencias Ambientales, Universidad de Concepción, Concepción, Chile, 12 March 1993. Unpublished. (In Spanish)

62. San Martín, C.; Subiabre, M.; Ramírez, Y. Estudio florístico y vegetacional de una gradiente latitudinal en marismas del Centro-Sur de Chile. Cienc. Investig. Agrar. 2006, 33, 37-45. (In Spanish)

63. Sea Level Station Monitoring Facility. Available online: http:/ /www.ioc-sealevelmonitoring.org/station.php?code=crnl2 (accessed on 15 May 2019).

64. Devynck, J. Contribución al Estudio de la Circulación Atmosférica en Chile y el Clima de la Región del Biobío; Memoria de Título para optar al Título Meteorólogo, Universidad de Concepción: Concepción, Chile, 1970. Unpublished. (In Spanish)

65. Pineda, V. Evolución Paleogeográfica de la Península de Arauco Durante el Cretácico Superior-terciario. Memoria de Título para optar al Título de Geólogo; Universidad de Concepción: Concepción, Chile, 1983. Unpublished. (In Spanish)

66. Gelcich, S.; Castilla, J.C. Ecosystem services and abrupt transformations in a Coastal Wetland social-ecological system: TubulRaqui after the 2010 earthquake in Chile. Ecol. Soc. 2014, 19, 22. [CrossRef]

67. Lesser, G.; Roelvink, J.; van Kester, J.; Stelling, G. Development and validation of a three-dimensional morphological model. Coast. Eng. 2004, 51, 883-915. [CrossRef]

68. Booij, N.; Ris, R.C.; Holthuijsen, L.H. A third-generation wave model for coastal regions: 1. Model description and validation. J. Geophys. Res. Space Phys. 1999, 104, 7649-7666. [CrossRef]

69. Martínez, C.; Quezada, M.; Quezada, J. Métodos para el análisis de cambios históricos de la línea litoral en playas de ensenada. Nuevos ejemplos en Chile. In II Manual de Métodos en Teledetección Aplicada a la Prevención de Riesgos Naturales en el Litoral; Alcántara-Carrió, J., Montoya, I., Correa, I., Eds.; Programa Iberoamericano de Ciencia y Tecnología para el Desarrollo (CYTED); CYTED: Cambridge, UK, 2013; pp. 259-300. (In Spanish) 
70. Syvitski, J.P.M. Principles, Methods, and Application of Particle Size Analysis; Cambridge University Press: New York, NY, USA, 1991; p. 368.

71. Wentworth, C.K. A scale of grade and class terms for clastic sediments. J. Geol. 1922, 30, 377-392. [CrossRef]

72. Folk, R.L.; Ward, W.C. Brazos River bar [Texas]; a study in the significance of grain size parameters. J. Sediment. Res. 1957, 27, 3-26. [CrossRef]

73. Trask, P. Origin and Environment of Source Sediments of Petroleum; Gulf Publishing Company: Houston, TX, USA, $1932 ;$ p. 323.

74. Pawlowicz, R.; Beardsley, B.; Lentz, S. Classical tidal harmonic analysis including error estimates in MATLAB using T_TIDE. Comput. Geosci. 2002, 28, 929-937. [CrossRef]

75. Hidrotop Ingeniería Ltda. Topo-Batimetric Survey of Tubul; Tech Report; Prepared for MOP (Ministry of Public Works, Chile): Santiago, Chile, 2008; p. 29.

76. Perillo, G.; Piccolo, M. Methodology to study estuarine cross-sections. Rev. Geofís. 1993, 38, 189-206.

77. Madden, C.; Goodin, K.; Allee, R.; Bamford, D.; Kinkbeiner, M. Clasificación Ecológica Estandarizada Costera y Marina-Versión III: La Clasificación de Referencia para Hábitats Marinos para la Red Temática de Ecosistemas IABIN; Nature Serve: Arlington, VA, USA, 2008; p. 36. (In Spanish)

78. Servicio Hidrográfico y Oceanográfico de la Armada de Chile (SHOA). Instrucciones Oceanográficas; No. 2; Armada de Chile: Edificio Armada de Chile: Valparaiso, Chile, 1999. (In Spanish)

79. Shimwell, D. The Description and Classification of Vegetation; Sidewick \& Jackson: London, UK, 1972.

80. Matthei, O. Manual de las Malezas que Crecen en Chile; Alfabeta Impresores: Santiago, Chile, 1995; 545p. (In Spanish)

81. Hoffmann, A. Flora Silvestre de Chile. Zona Central; Cuarta Edición; Ediciones Fundación Claudio Gay: Santiago, Chile, 1998; 254p. (In Spanish)

82. Riedemann, P.; Aldunate, G. Flora Nativa De Valor Ornamental. Identificación y Propagación: Chile, Zona Sur; Editorial Andrés Bello: Santiago, Chile, 2003; 517p. (In Spanish)

83. Riedemann, P.; Aldunate, G. Flora Nativa De Valor Ornamental. Identificación y Propagación: Chile, Zona Centro; Editorial Andrés Bello: Santiago, Chile, 2004; 567p. (In Spanish)

84. Rodriguez, R.; Dellarosa, V. Plantas vasculares acuáticas en la región del Biobio; Editorial Universidad de Concepción: Concepción, Chile, 1998; p. 3. (In Spanish)

85. Simpson, E. Measurement of diversity. Nature 1949, 163, 688. [CrossRef]

86. Quinn, G.P.; Keough, M.J. Experimental Design and Data Analysis for Biologists; Cambridge University Press: Cambridge, UK, 2002; $557 \mathrm{p}$.

87. Pielou, E. Ecological Diversity; John Wiley: New York, NY, USA, 1975.

88. Hammer, O.; Harper, D.; Ryan, P. PAST: Paleontological Statistics Software Package for Education and Data Analysis, Version 2.00. Palaeontol. Electrón. 2001, 4, 9. Available online: http://palaeoelectronica.org/2001_1/past/issue1_01.htm (accessed on 25 June 2020).

89. Ris, R.; Booij, N.; Holthuijsen, L. A third-generation wave model for coastal regions, 2. Verification. J. Geophys. Res. 1999, 104, 7667-7681. [CrossRef]

90. Van Rijn, L.C. Principles of Sediment Transport in Rivers, Estuaries and Coastal Seas; AQUA Publications: Blokzijl, The Netherlands, 1993.

91. Stive, M.; Roelvink, J.; De Vriend, H. Large-Scale Coastal Evolution Concept. In Proceedings of the 22nd International Conference on Coastal Engineering; ASCE: New York, NY, USA, 1990.

92. Roelvink, J. Coastal morphodynamic evolution techniques. Coast. Eng. 2006, 53, 277-287. [CrossRef]

93. Gómez, M.; Villagrán, M.; Martínez, C.; Belmonte, A. Characterizing the longshore sediment transport pattern on beaches in the Gulf of Arauco, Chile, to assess morphological shoreline evolution. J. Coast. Res. 2018, 85, 656-660. [CrossRef]

94. The WAVEWATCH III®Development Group (WW3DG). User Manual and System Documentation of WAVEWATCH III®Version 5.16; Tech. Note 329, NOAA/NWS/NCEP/MMAB; U. S. Department of Commerce, National Oceanic and Atmospheric Administration, National Weather Service, National Centers for Environmental Prediction: College Park, MD, USA, 2016; 326p.

95. Quezada, J.; Jaque, E.; Fernández, A.; Vásquez, D. Cambios en el relieve generados como consecuencia del terremoto Mw = 8,8 del 27 de Febrero de 2010 en el Centro-sur de Chile. Rev. Geogr. Norte Gd. 2012, 53, 35-55. (In Spanish) [CrossRef]

96. Lomnitz, C. Major earthquakes and tsunamis in Chile during the period 1535 to 1955. Soderdruck Geol. Rundsch. Band 1970, 59, 938-960. [CrossRef]

97. Lagos, M. Tsunamis de origen cercano a las costas de Chile. Rev. Geogr. Norte Gd. 2000, 27, 93-102. (In Spanish)

98. Cisternas, M.; Melnick, D.; Ely, L.; Wesson, R.; Norambuena, R. Similarities between the great Chilean earthquakes of 1835 and 2010. In Proceedings of the American Geophysical Union Chapman Conference, Valparaíso, Viña del Mar and Valdivia, Chile, 16-24 May 2010; p. 19.

99. Palacios, A. Sismicidad Histórica de la Ciudad de Concepción Desde su Fundación en 1550 Hasta su Traslado en 1751; Boletín No. 64; Servicio Nacional de Geología y Minería: Santiago, Chile, 2012. (In Spanish)

100. Vigny, C.; Socquet, A.; Peyrat, S.; Ruegg, J.-C.; Metois, M.; Madariaga, R.; Morvan, S.; Lancieri, M.; Lacassin, R.; Campos, J.; et al. The $2010 \mathrm{Mw} 8.8$ maule megathrust earthquake of Central Chile, Monitored by GPS. Science 2011, 332, 1417-1421. [CrossRef]

101. Veyl, C. Los Fenómenos Volcánicos y Sísmicos de Fines de Mayo de 1960 en el Sur de Chile; Departamento de Geología y Mineralogía, Instituto Central de Química, Universidad de Concepción: Concepción, Chile, 1960; 42p. (In Spanish) 
102. Gallo, M.; Rodríguez, E. Caracterización de Paisajes y Ecosistemas: Proyecto Demostrativo Cuenca Baja del río Paz el Salvador-Guatemala; Proyecto Humedales y Medios de Vida; Wetlands International: Wageningen, The Netherlands, 2010; pp. 1-41. (In Spanish)

103. Adam, P. Saltmarsh Ecology; Cambridge University Press: Cambridge, UK, 1990.

104. Chapman, V.J. Salt marshes and salt deserts of the world. Ecol. Halophytes 1974, 79, 3-19.

105. Figueroa, R.; Valdovinos, C. Productividad de pastizales salinos del estuario Lenga (Chile) a escala de paisaje ecológico: Análisis de imágenes Landsat TM y experimentos in situ. Bol. Soc. Biol. Concepción 1997, 68, 7-11. (In Spanish)

106. Stuardo, J.; Valdovinos, C.; Figueroa, R.; Occhipinti, A. Ambientes costeros del Golfo de Arauco y áreas adyacentes. Publ. EU-LA-Chile. Ser. Mon. Cient. 1992, 9, 1-157. (In Spanish)

107. Winckler, P.; Contreras-López, M.; Campos-Caba, R.; Beyá, J.F.; Molina, M. El temporal del 8 de agosto de 2015 en la región de Valparaíso, Chile Central. Lat. Am. J. Aquat. Res. 2017, 45, 622-648. (In Spanish) [CrossRef]

108. Martínez, C.; Contreras-López, M.; Winckler, P.; Hidalgo, H.; Godoy, E.; Agredano, R. Coastal erosion in central Chile: A new hazard? Ocean Coast. Manag. 2018, 156, 141-155. [CrossRef]

109. Martínez, C.; Martínez, I.; Paredes, C.; Cienfuegos, R. ¿Por qué Chile Necesita Una Ley de Costas? Hacia Nueva Gobernanza de la Costa Para el Siglo XXI. Serie Policy Papers CIGIDEN. 2020. Available online: https://www.cigiden.cl/wp-content/uploads/ 2020/01/Por-que-Chile-necesita-una-ley-de-costas-1.pdf (accessed on 11 February 2021). (In Spanish).

110. Winckler, P.; Contreras-López, M.; Vicuña, S.; Larraguibel, C.; Mora, J.; Esparza, C.; Salcedo, J.; Gelcich, S.; Fariña, J.M.; Martínez, C.; et al. Amenazas en "Determinación del riesgo de los impactos del Cambio Climático en las costas de Chile"; Ministerio del Medio Ambiente: Santiago, Chile, 2019; Volume 1. (In Spanish)

111. Aránguiz, R.; Martínez, C.; Rojas, O.; Hoffmann, C.; López, P. The generation of new tsunami risk areas due to an intentionally biased reconstruction process: Case study of llico after the 2010 Chile tsunami. Int. J. Disaster Risk Reduct. 2020, $50,101727$. [CrossRef]

112. Martínez, C.; Rojas, O.; Villagra, P.; Aránguiz, R.; Sáez-Carrillo, K. Risk factors and perceived restoration in a town destroyed by the 2010 Chile tsunami. Nat. Hazards Earth Syst. Sci. 2017, 17, 721-734. [CrossRef]

113. Rojas, C.; Munizaga, J.; Rojas, O.; Martínez, C.; Pino, J. Urban development versus wetland loss in a coastal Latin American city: Lessons for sustainable land use planning. Land Use Policy 2019, 80, 47-56. [CrossRef]

114. Martínez, C.; López, P.; Rojas, C.; Qüense, J.; Hidalgo, R.; Arenas, F. A sustainability index for anthropized and urbanized coasts: The case of Concón Bay, central Chile. Appl. Geogr. 2020, 116, 102166. [CrossRef]

115. Espejo, D.H. Noción y elementos de la justicia ambiental: Directrices para su aplicación en la planificación territorial y en la evaluación ambiental estratégica. Rev. Derecho 2010, 23, 9-36. (In Spanish) [CrossRef]

116. Zhao, L.; Liu, F. Land-use planning adaptation in response to SLR based on a vulnerability analysis. Ocean Coast. Manag. 2020, 196, 105297. [CrossRef] 